\title{
Phylogenetic relationships and biogeographical patterns in Circum-Mediterranean subfamily Leuciscinae (Teleostei, Cyprinidae) inferred from both mitochondrial and nuclear data
}

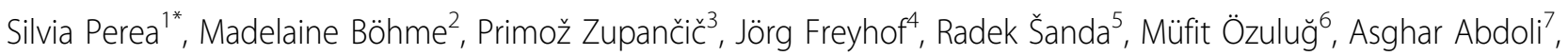
Ignacio Doadrio'

\begin{abstract}
Background: Leuciscinae is a subfamily belonging to the Cyprinidae fish family that is widely distributed in Circum-Mediterranean region. Many efforts have been carried out to deciphering the evolutionary history of this group. Thus, different biogeographical scenarios have tried to explain the colonization of Europe and Mediterranean area by cyprinids, such as the "north dispersal" or the "Lago Mare dispersal" models. Most recently, Pleistocene glaciations influenced the distribution of leuciscins, especially in North and Central Europe. Weighing up these biogeographical scenarios, this paper constitutes not only the first attempt at deciphering the mitochondrial and nuclear relationships of Mediterranean leuciscins but also a test of biogeographical hypotheses that could have determined the current distribution of Circum-Mediterranean leuciscins.

Results: A total of 4439 characters (mitochondrial + nuclear) from 321 individuals of 176 leuciscine species rendered a well-supported phylogeny, showing fourteen main lineages. Analyses of independent mitochondrial and nuclear markers supported the same main lineages, but basal relationships were not concordant. Moreover, some incongruence was found among independent mitochondrial and nuclear phylogenies. The monophyly of some poorly known genera such as Pseudophoxinus and Petroleuciscus was rejected. Representatives of both genera belong to different evolutionary lineages. Timing of cladogenetic events among the main leuciscine lineages was gained using mitochondrial and all genes data set.
\end{abstract}

Conclusions: Adaptations to a predatory lifestyle or miniaturization have superimposed the morphology of some species. These species have been separated into different genera, which are not supported by a phylogenetic framework. Such is the case of the genera Pseudophoxinus and Petroleuciscus, which real taxonomy is not well known. The diversification of leuciscine lineages has been determined by intense vicariant events following the paleoclimatological and hydrogeological history of Mediterranean region. We propose different colonization models of Mediterranean region during the early Oligocene. Later vicariance events promoted Leuciscinae diversification during Oligocene and Miocene periods. Our data corroborate the presence of leuciscins in North Africa before the Messinian salinity crisis. Indeed, Messinian period appears as a stage of gradually Leuciscinae diversification. The rise of humidity at the beginning of the Pliocene promoted the colonization and posterior isolation of newly established freshwater populations. Finally, Pleistocene glaciations determined the current European distribution of some leuciscine species.

\footnotetext{
* Correspondence: sperea@mncn.csic.es

'Museo Nacional de Ciencias Naturales-CSIC. Department of Biodiversity and

Evolutionary Biology. José Gutiérrez Abascal 2, 28006 Madrid. Spain

Full list of author information is available at the end of the article
} 


\section{Background}

Mediterranean freshwater fish fauna is characterized by a relatively low number of fish families, with most of the species belonging to Cyprinidae [1,2]. In effect, this family is among the most speciose families of freshwater fishes and likely to be one of the largest vertebrate families [3]. The family Cyprinidae also features a relatively high number of endemic species on the Mediterranean slope [2] and its wide biological and ecological plasticity has bestowed this group an important role in biogeographical models [4-7]. As dispersion mechanisms are highly restricted in primary freshwater fishes [8], their distributions are directly related to paleogeography and relationships among different areas [9-11]. Thus, phylogenetic relationships among evolutionary lineages reflect the history of cyprinids within the Mediterranean region.

The classification of cyprinids has always been a matter of controversy and from 2 to 12 subfamilies have been recognized depending on author and the morphological traits considered [12-15] and even have been recently elevated to family level, being assigned European and North American leuciscins and phoxinins to the new called family Leuciscidae [16,17]. Traditional morphology, however, sometimes conflicts with the more recent molecular studies [5,18-23] because some morphological characters are prone to homoplasy [5] and usually there is unclear homology of morphological traits $[24,25]$. This determines that recognized monophyletic groups are clearly misinterpreted. In this paper, we followed the classification scheme of Saitoh et al. [22] based on complete mitochondrial genomes. These authors consider the subfamily Leuciscinae exclusively formed by the Eurasian and North African leuciscins (including the North American genus Notemigonus, as the only known representative in this region) and promote phoxinins [15] to their own subfamily, Phoxininae, as the sister group of the subfamily Leuciscinae. To date, however, the nuclear phylogenetic relationships of cyprinids, and particularly leuciscins, have been little explored [26,27].

The fossil record of Cyprinidae family in Eurasia [28-30] suggests its origin in East and Southeast Asia, where greatest generic and species diversity is found $[1,3,31]$. This group then colonized Europe for the first time during the Oligocene period when the Ob Sea disappeared because of the uplifting of the Urals, and reached the Iberian Peninsula (the westernmost part of Europe) in the late Oligocene-early Miocene [32]. The colonization of North Africa has been explained by connections with Iberian and Asian fish faunas during Cenozoic period [33]. Within the family Cyprinidae, the subfamily Leuciscinae may be used to test biogeographical hypotheses for the Mediterranean basin.
In addition, owing to its long-standing distribution range in the Circum-Mediterranean area it should be possible to unravel the evolutionary history of this group.

Traditional hypotheses have proposed the origin of the subfamily Leuciscinae in the Mediterranean area and its subsequent diversification through river captures from central Europe as several waves stretched across a long time period (from the Oligocene until late Pliocene, 351.7 mya) [34,35], following the hydrogeographical and geological history of the European area [36]. This model has been designated as the "north dispersal model" [37]. Hypotheses opposing this model have argued that the colonization of Circum-Mediterranean rivers cannot be explained by a northern route. The alternative model proposed is based on leuciscine dispersion during the lacustrine stage of the Mediterranean basin [38], when this sea became refilled with fresh water from Paratethys Sea during the Messinian salinity crisis [39]. This would have allowed Paratethyan freshwater icthyofauna to colonize the Mediterranean margins. This hypothesis is described as the "Lago Mare" dispersal model [38]. The later opening of the Straits of Gibraltar [40] filled the Mediterranean area with marine water, with the subsequent isolation of the new-formed freshwater populations along with intense vicariant events $[41,42]$. However, the Lago Mare and north dispersal hypotheses are not mutually exclusive and together could have played an important role on dispersal of cyprinids across Europe $[1,11,43]$. On the other hand, the Middle East has been considered an important interchange area for freshwater ichthyofauna during the gradual closing of the Tethys Sea $[6,44,45]$. It is in fact held by some authors that the Middle Eastern freshwater fauna is made up of species that came from Asia and more recently from Euromediterranean ancestors $[6,45,46]$. The basis for this latter proposal is the close affinity found between Middle Eastern and Euromediterranean cyprinids [6,47]. This region has been also recognized as a center of origin for some Leuciscinae species $[6,11,48]$.

Most recently, Pleistocene glaciations influenced the distribution of Leuciscinae representatives, especially in North and Central Europe, where some species became locally extinct when the region was covered by ice $[35,49]$. Later recolonization from eastern refuges such as Circum-Black Sea drainages has been suggested to explain the wide distribution of some extant cyprinid species [11,50,51]. Although the Mediterranean Peninsulas and Caspian/Caucasus region are known to have acted as glacial refuges [52,53], the Iberian, Italian and Balkan Peninsulas were isolated from northern and central Europe because of the Alps uplift during the Pleistocene thus preventing most Mediterranean freshwater species moving northwards. This interpretation explains 
the low level of shared freshwater species between north-central and southern Europe.

Weighing up all biogeographical scenarios, some models have attempted to explain the center of origin and the main dispersion routes for cyprinids $[1,6,11,34-36$, $47,48,54,1]$, while others have tried to identify barriers to explain the vicariant patterns observed in cyprinid fishes $[4,5,14,25,32,33,37,43,55]$. Despite these efforts, the phylogenetic relationships of Circum-Mediterranean leuciscins and their biogeographical patterns in Mediterranean area remain unclear.

To obtain reliable information on the mitochondrial phylogenetic structure of this group, the comprehensive study examines mitochondrial DNA in numerous species of the subfamily Leuciscinae. Indeed, sequences of the cytochrome $b$ (cyt $b$ ) gene have achieved phylogenetic resolution in some fish groups [56,57], including cyprinids $[4-7,11,18,20,37,43,48,58]$. In turn the cytochrome oxidase I (COxI) gene has also proved to be a useful tool for the identification of fish species $[59,60]$. Here we complete the mitochondrial phylogeny of the subfamily Leuciscinae using nuclear information by analyzing the Recombination Activating Gene 1 (RAG-1) and the Ribosomal Protein Gene S7 (S7). Only a few previous molecular studies on cyprinids have yielded a nuclear phylogeny of Circum-Mediterranean representatives of the subfamily Leuciscinae. Some leuciscine groups have been examined using nuclear allozymes $[10,61,62]$ or DNA sequences [63-65] approaches and some phylogenetic relationships have been proposed for cyprinids [66]. However, this paper constitutes the first attempt at deciphering the nuclear relationships of the main Mediterranean Leuciscinae lineages based on sequences data.

The aim of this exhaustive study was to investigate phylogenetic relationships among the major CircumMediterranean Leuciscinae lineages by analyzing sequence variation of both mitochondrial (cyt $b$ and COxI) and nuclear (RAG-1 and S7) genes. Data were obtaining for 321 individuals representing 176 species of the subfamily Leuciscinae and 9 outgroup species. The data were used to test for biogeographical events that could have determined the distribution of leuciscins in Mediterranean area.

\section{Results}

\section{Leuciscinae phylogenetic performance}

Out of a total of 4439 characters obtained, 1786bp corresponded to mitochondrial DNA and 2653bp to nuclear DNA. Table 1 compares the phylogenetic performance of the individual genes under the taxon sampling in phylogenetic analyses. ML parameters estimated using Modeltest v3.7 [67] are provided in Table 2. The $\chi^{2}$ test for base homogeneity indicated that base frequency distributions were always homogenous among taxa. The nuclear genes showed much higher consistency (CI) and retention (RI) indices, while the mitochondrial genes offered more parsimony informative (PI) sites. Indeed, the proportion of informative sites showed by cyt $b$ gene was the highest (Table 1 ).

\section{Mitochondrial phylogenetic relationships}

All mitochondrial analyses generated almost identical and well-supported topologies. Our discussion therefore focuses on the more resolved Bayesian tree and the results of the Maximum likelihood (ML) and Maximum Parsimony (MP) analyses are summarized. Bayesian analysis $[68,69]$ has been empirically demonstrated to be the most efficient character-based method for accurately reconstructing a phylogeny [70].

According to our molecular mitochondrial cyt $b$ data, the subfamily Leuciscinae comprises fourteen major monophyletic lineages. All lineages were supported by high posterior probability and bootstrap values (Figure 1).

Lineage I was formed by the monotypic North American genus Notemigonus ( $N$. crysoleucas). Lineage II comprised the widespread genus Alburnus, the monotypic genera Leucaspius and Anaecypris and the North African species Pseudophoxinus punicus. Although L. delineatus appeared as more related with $P$. punicus, this relationship was not highly supported (Figure 2). Lineage III was formed by the genus Scardinius. Lineage IV comprised the two species of the Greek genus Tropidophoxinellus and the two North African species Pseudophoxinus chaignoni and P. callensis. Lineage $\mathrm{V}$ included the genera Squalius, Ladigesocypris (L. ghigii and L. irideus) and two species of Petroleuciscus (P. borysthenicus and P. smyrnaeus) (Figure 3). The genus Squalius was subdivided into two well-differentiated clades. The

Table 1 Comparison of the phylogenetic performance for each individual gene and the combined data set

\begin{tabular}{|c|c|c|c|c|c|c|c|}
\hline$\overline{\text { GENE }}$ & $\begin{array}{l}\text { TOTAL } \\
\text { CHARACTERS }\end{array}$ & $\begin{array}{l}\text { PARSIMONY INFORMATIVE } \\
\text { CHARACTERS (in \%) }\end{array}$ & $\begin{array}{l}\text { Tv/Ts } \\
\text { RATE }\end{array}$ & $\begin{array}{l}\text { LENGTH } \\
\text { parsimony tree }\end{array}$ & $\mathrm{Cl}$ & $\mathbf{R I}$ & $\mathrm{HI}$ \\
\hline $\mathrm{CYT} \mathrm{B}$ & 1140 & $562(49.29 \%)$ & 5.45 & 8995 & 0.233 & 0.769 & 0.882 \\
\hline$\overline{\operatorname{COxl}}$ & 646 & $242(37.46 \%)$ & 0.79 & 2322 & 0.199 & 0.797 & 0.801 \\
\hline NUCLEAR DATA SET (RAG1+S7) & 2647 & $600(22.66 \%)$ & 0.87 & 2531 & 0.637 & 0.795 & 0.363 \\
\hline $\begin{array}{l}\text { COMBINED GENES (Cytb+COxl } \\
+ \text { RAG1+S7) }\end{array}$ & 4339 & $1258(28.37 \%)$ & 1.94 & 10913 & 0.371 & 0.556 & 0.729 \\
\hline
\end{tabular}


Table 2 Parameters of ML analyses estimated with Modeltest under Akaike criterion

\begin{tabular}{|c|c|c|c|c|}
\hline & Cytb & COxI & RAG1 & S7 \\
\hline $\begin{array}{l}\text { Model selected by Modeltest } \\
\text { (AIC criteria) }\end{array}$ & GTR+I+G & GTR+I+G & $\mathrm{K} 81+\mathrm{G}$ & $\mathrm{K} 81+\mathrm{G}$ \\
\hline \multirow[t]{6}{*}{ Rates substitution matrix } & {$[A-C]=0.61$} & {$[\mathrm{~A}-\mathrm{C}]=1.00$} & {$[\mathrm{~A}-\mathrm{C}]=1.93$} & {$[\mathrm{~A}-\mathrm{C}]=1.00$} \\
\hline & {$[A-G]=26.57$} & {$[\mathrm{~A}-\mathrm{G}]=17.05$} & {$[A-G]=5.09$} & {$[A-G]=1.56$} \\
\hline & {$[\mathrm{A}-\mathrm{T}]=0.35$} & {$[\mathrm{~A}-\mathrm{T}]=1.00$} & {$[\mathrm{~A}-\mathrm{T}]=1.23$} & {$[A-T]=0.64$} \\
\hline & {$[\mathrm{C}-\mathrm{G}]=1.62$} & {$[C-G]=1.00$} & {$[C-G]=0.54$} & {$[C-G]=0.64$} \\
\hline & {$[C-T]=6.60$} & {$[C-T]=9.43$} & {$[C-7]=5.09$} & {$[C-T]=1.56$} \\
\hline & {$[\mathrm{G}-\mathrm{T}]=1.00$} & {$[\mathrm{G}-\mathrm{T}]=1.00$} & {$[\mathrm{G}-\mathrm{T}]=1.00$} & {$[\mathrm{G}-\mathrm{T}]=1.00$} \\
\hline Assumed proportion of invariable sites (I) & 0.36 & 0.57 & 0 & 0 \\
\hline Alpha (G) & 0.65 & 0.98 & 0.46 & 1.02 \\
\hline
\end{tabular}

"S. cephalus species group" clade, which was in turn structured into two subclades: the first subclade included central European and Mediterranean species while the second subclade consisted of Anatolian and Caucasian species. The second large Squalius clade was structured into three subclades: the Iberian subclade, the Adriatic subclade and the Greece subclade formed by the species S. keadicus. Ladigesocypris were nested into the Squalius clade and Petroleuciscus were positioned basal to all species of Squalius. Lineage VI was comprised of the former genus Chondrostoma s.l., which has been recently subdivided into six genera [64]: Achondrostoma, Chondrostoma, Iberochondrostoma, Parachondrostoma, Protochondrostoma and Pseudochondrostoma. The genera Phoxinellus, Telestes and the Anatolian representatives of the genus Pseudophoxinus also clustered in this lineage (Figure 4). Phoxinellus and Chondrostoma s.l., together represented the sister group of Telestes and the Anatolian Pseudophoxinus. The Anatolian Pseudophoxinus species were represented by two monophyletic and well-differenciated clades: one of them including the species $P$. alii, $P$. anatolicus, $P$. antalyae, P. battalgilae, P. crassus, P. elizevetae, P. evliyae, $P$. fahretinne, $P$. ninae and one possibly undescribed species. The second one was formed by $P$. firati, P. kervillei, $P$. zekayi and $P$. zeregi. Lineage VII constituted the genus Rutilus and lineage VIII contained the genera Abramis, Acanthobrama, Acanthalburnus, Ballerus, Blicca, Mirogrex and Vimba, together with the Iranian species Petroleuciscus persidis. Lineage IX was exclusively represented by the genus Alburnoides. Lineage X was composed by the genera Aspius and Leuciscus. Lineage XI was comprised only by the species Pseudophoxinus egridiri. Lineage XII was formed by the genus Pachychilon. Lineage XIII comprised the genera Pelasgus and Delminichthys. Finally lineage XIV was formed by the monotypic genus Pelecus, which was the first lineage to split.

The cytochrome oxidase I gene (COxI) rendered the same main lineages as cytochrome $b$ but also detected a deep politomy among all lineages (Figure 5). Thus, excluded Pelecus basal to the remaining leuciscine lineages with regarding to the phylogenetic relationships between different lineages, deep relationships between them were not well solved with mitochondrial markers.

Moreover, some incongruence was found among cyt $b$ and COxI topologies, such as Pseudophoxinus punicus, which was more related with $P$. callensis than with the Alburninae group, as well as Pachychilon, which was closer to Alburnoides lineage than to Pelasgus-Delminichthys and Pseudophoxinus egridiri lineages. On the other hand, the Lineages II (Alburnus, Anaecypris, Leucaspius and Pseudophoxinus punicus), III (Scardinius) and IV (Pseudophoxinus callensis, P. chaignoni, Tropidophoxinellus) were clustered together and highly support with cytochrome $b$, but were unrelated with COxI gene.

\section{Nuclear phylogenetic relationships}

Although the number of species is lesser in nuclear analyses than in mitochondrial one, the topologies of both mitochondrial and combined nuclear genes (RAG1 + S7) support the identical major lineages. However, deep relationships among lineages were not solved with nuclear markers (Figure 6). Even within some lineages as number VI (Chondrostoma s.l., Telestes and Anatolian Pseudophoxinus) basal relationships were not solved. As occurred in COxI topology, the lineages II, III and IV were unrelated with nuclear genes. Moreover, some incongruence was found between mitochondrial and nuclear data. Such is the case of Pachychilon, which was not related with Pelasgus-Delminichtys-Pseudophoxinus egridiri. In turn, P. egridiri was nested, and highly support, within Pelasgus-Delminichthys lineage.

\section{Phylogenetic relationships with all-genes data matrix}

Combined data analysis recovered the major lineages and increased their support (posterior probabilities and bootstrap values higher than only mitochondrial and nuclear analysis) (Figure 7). Indeed, this effect can be explained because large number of variable characters 


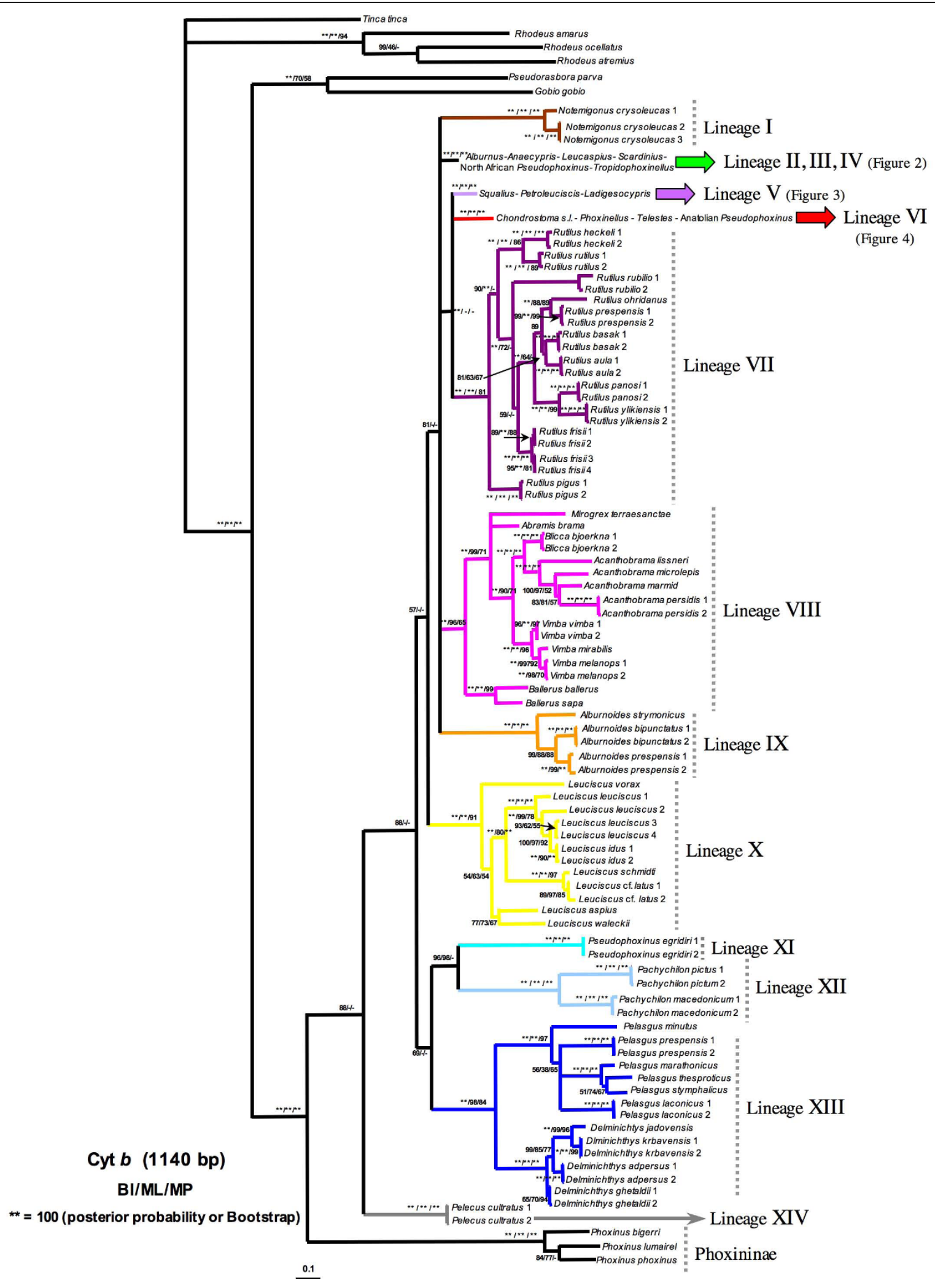

Figure 1 Phylogenetic tree rendered by Bayesian analysis of the mitochondrial cytochrome $\boldsymbol{b}$ data set. Numbers above branches means posterior probabilities of BI/Bootstrap values of ML/Bootstrap values of MP. 


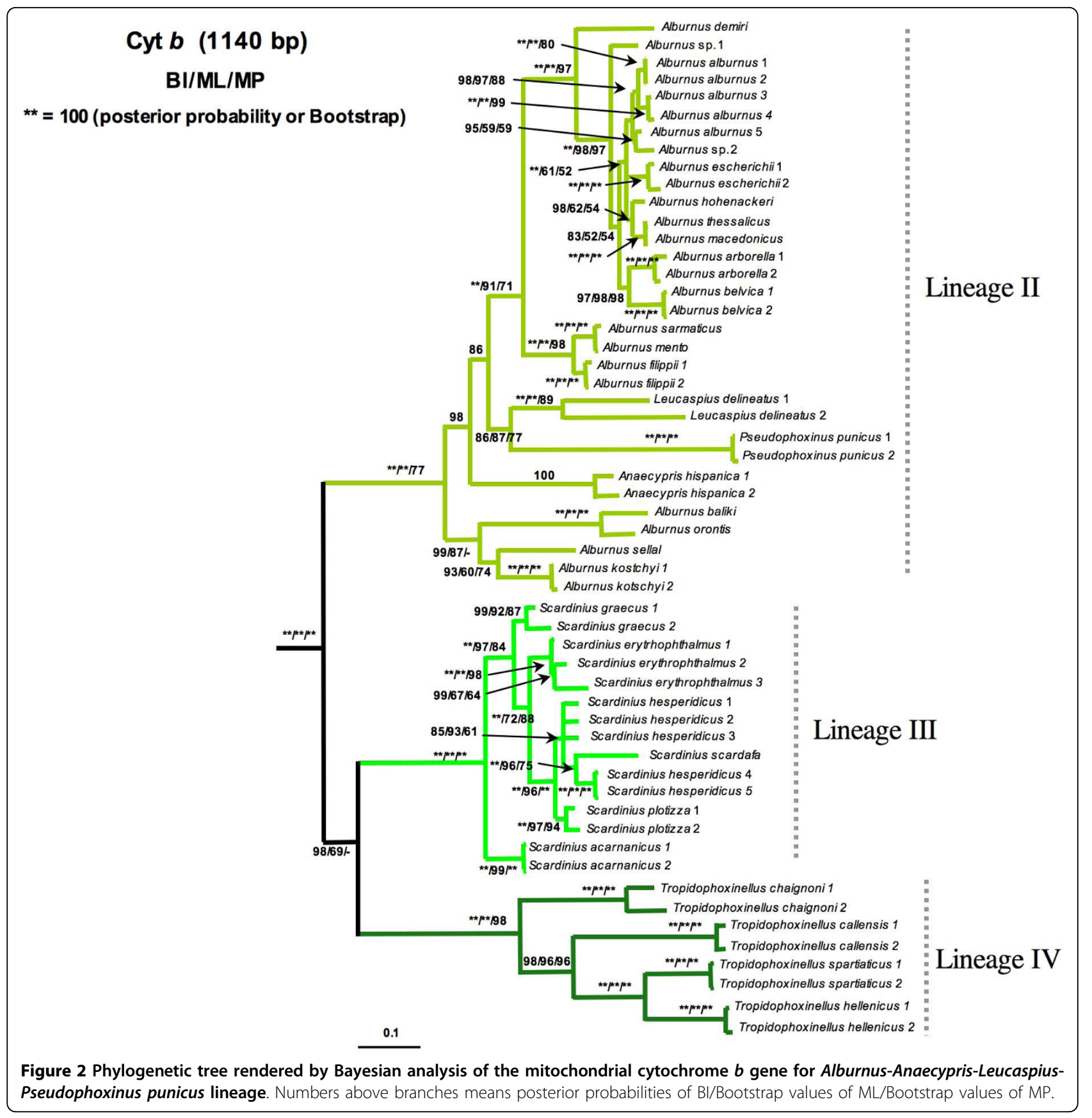

can improve the accuracy of reconstructed relationships [71]. Nevertheless, the topology of combined data was very similar to that obtained by cytochrome $b$, due to the higher number of informative-parsimony characters of this gene respect to the others (Table 1).

\section{Divergence time}

A relaxed molecular clock was performed based on mitochondrial cytochrome $b$ gene (not showed) and allgenes data set. Our analysis supports the divergence of the main lineages occurred in Late Oligocene-Early Miocene. The timing of splitting-events of the CircumMediterranean leuciscine lineages is reported in Figure 8 .

\section{Discussion}

Phylogenetic relationships of Leuciscinae lineages

Although our study is focused on the Circum-Mediterranean Leuciscinae representatives, the inclusion of the majority of west Paleartic lineages allowed a more 


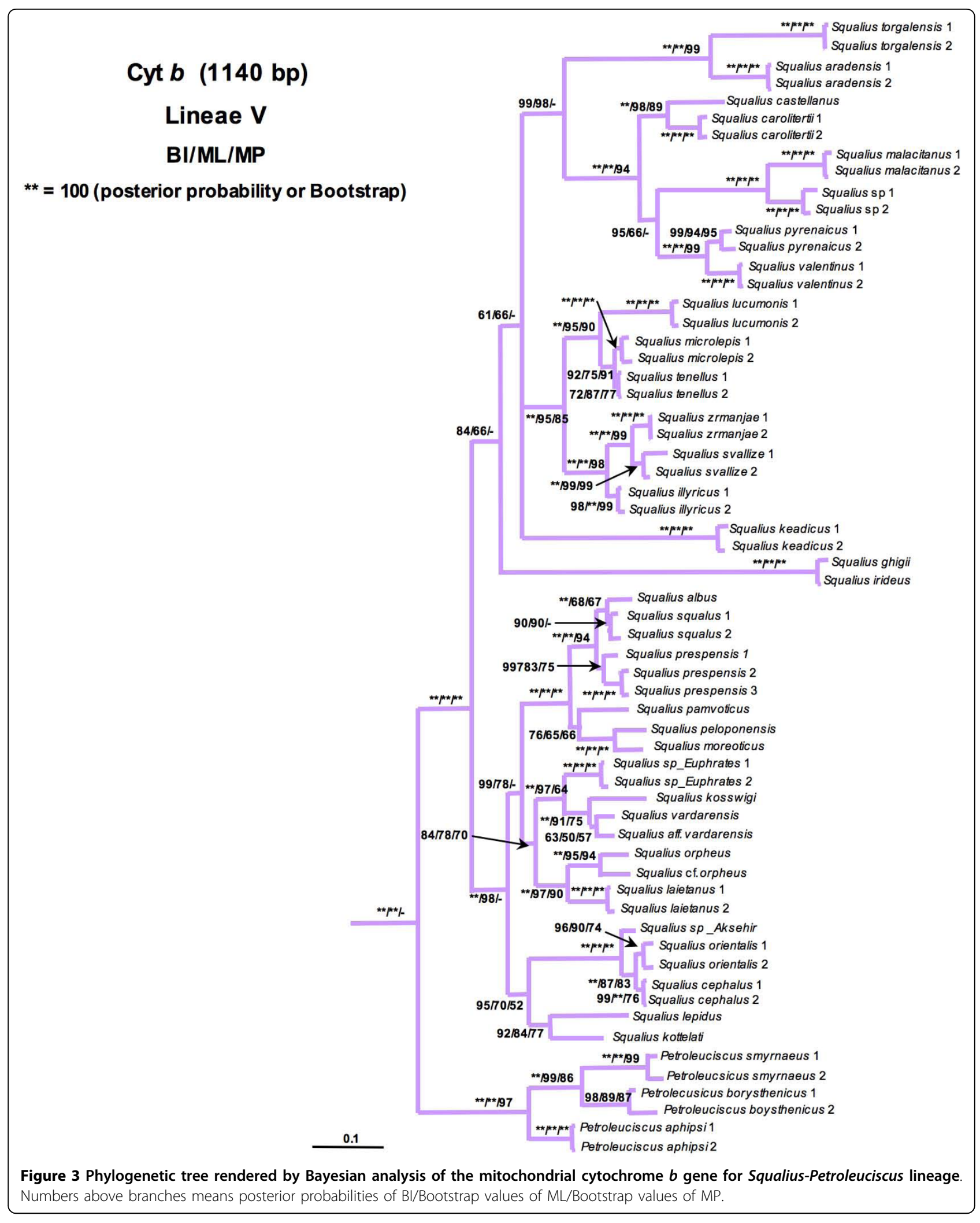




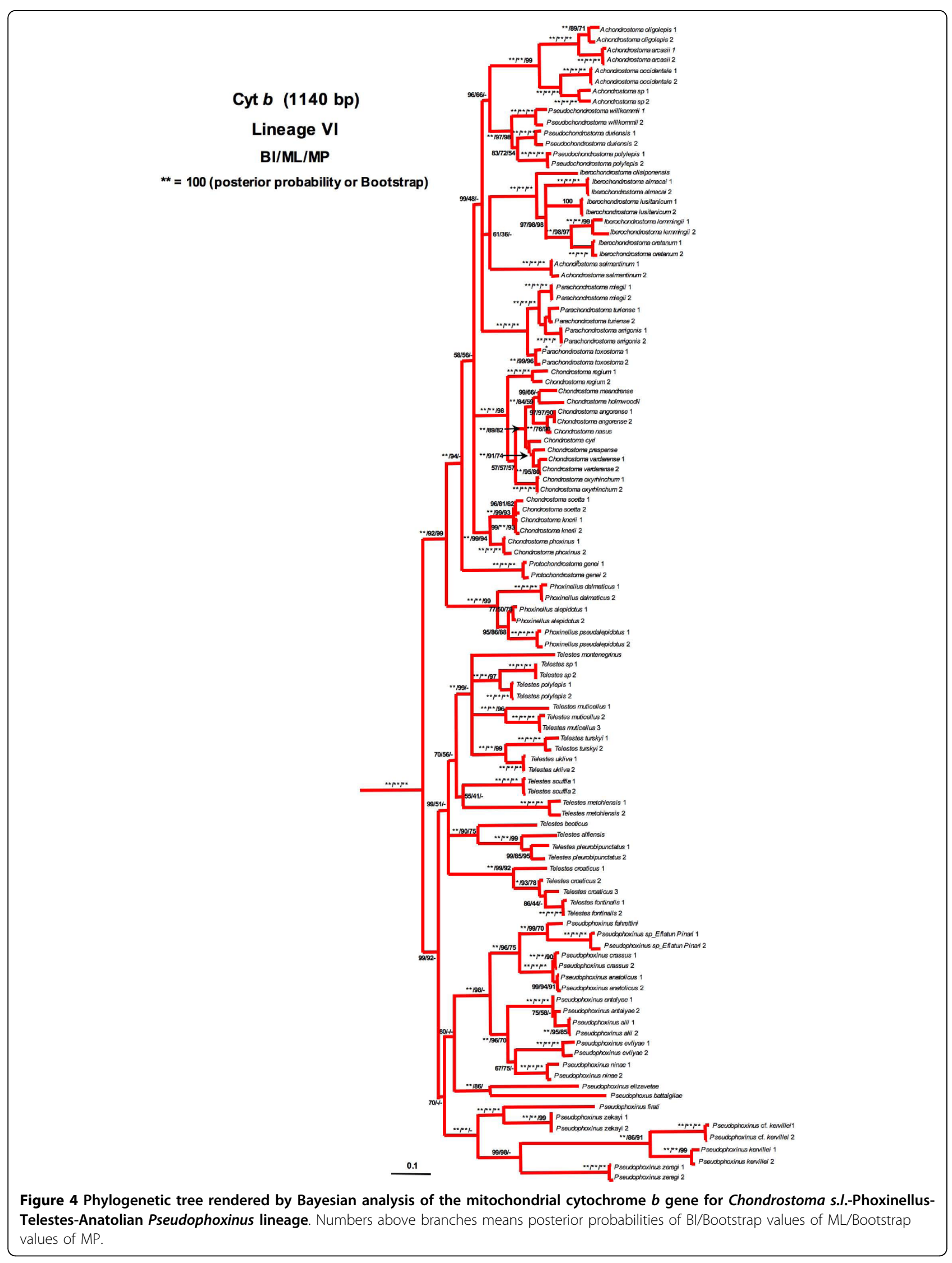




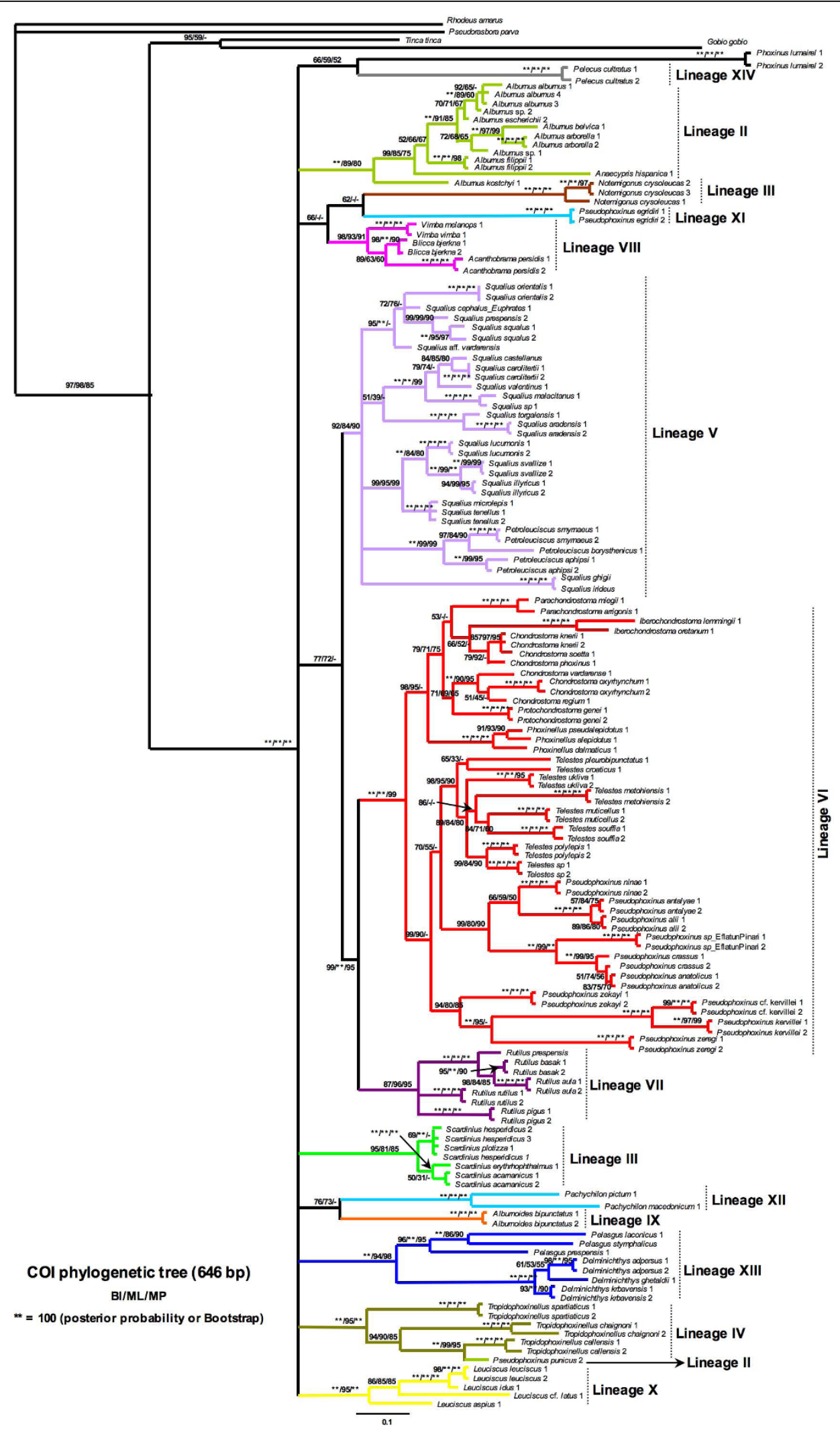

Figure 5 Phylogenetic tree rendered by Bayesian analysis of the mitochondrial cytochrome oxidase I gene. Numbers above branches means posterior probabilities of Bl/Bootstrap values of ML/Bootstrap values of MP. 


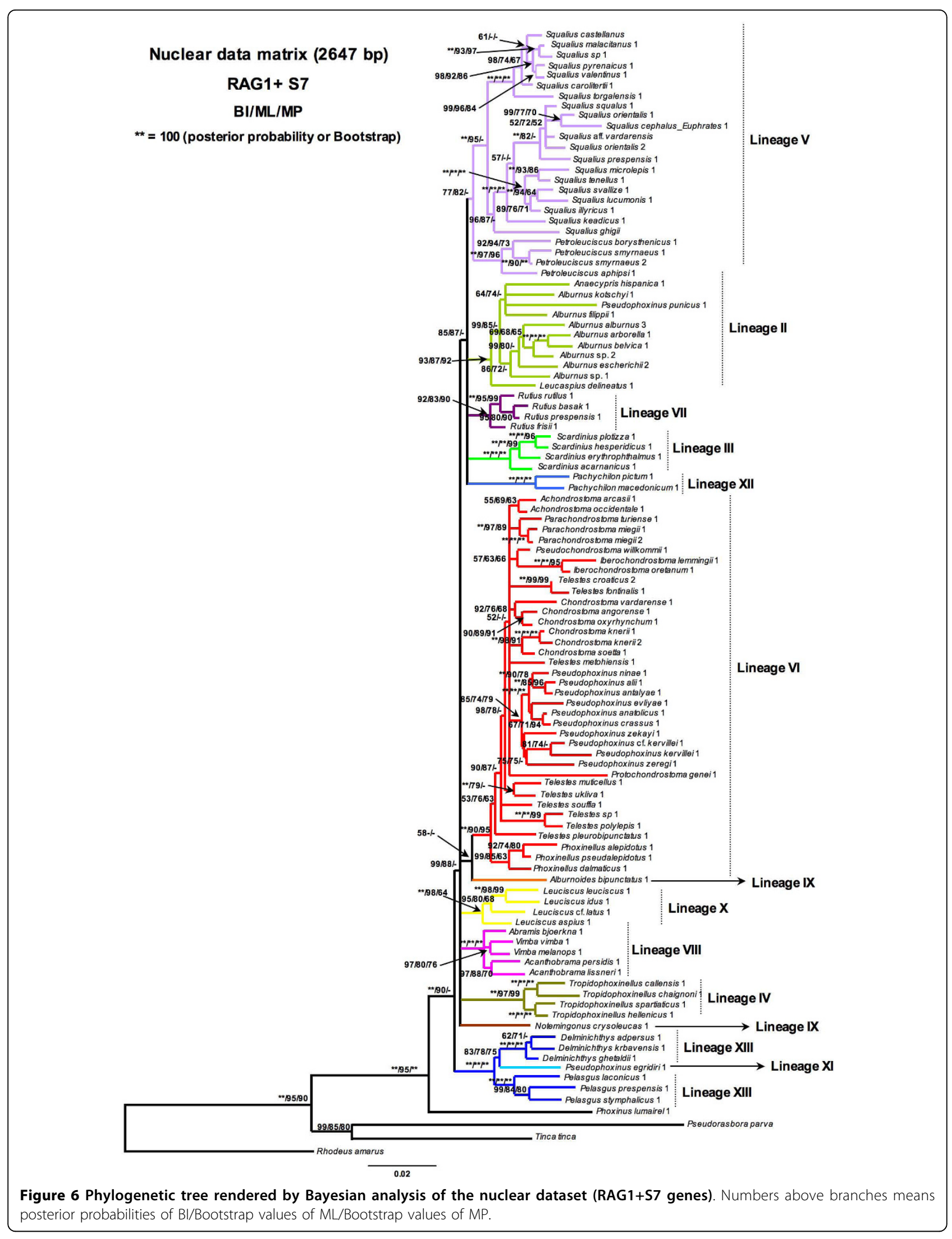




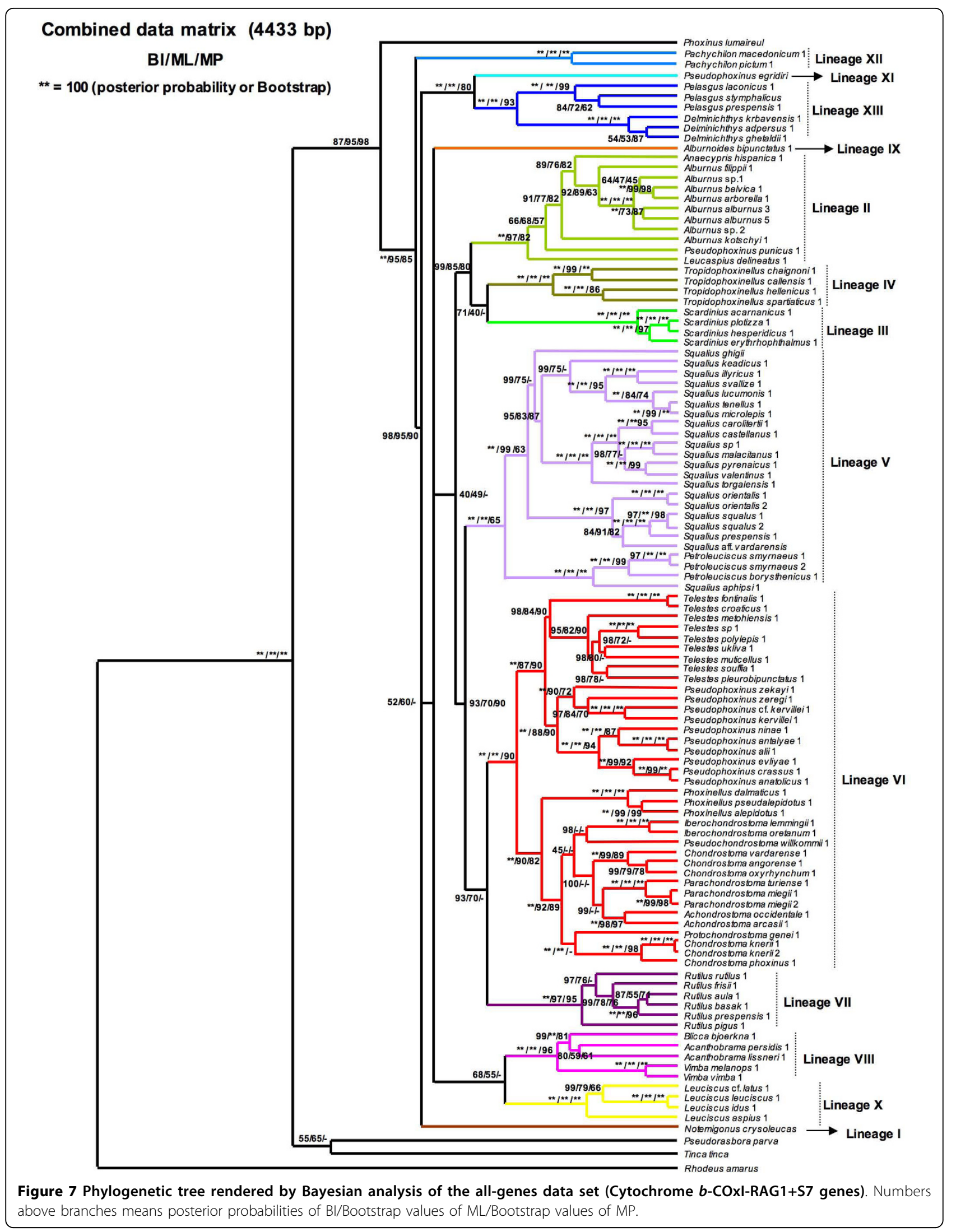




\section{Divergence time estimations \\ Combined data matrix (4433 bp) \\ Black numbers: $\mathrm{BI}$ posterior probabilities \\ ${ }^{\star *}=100$ (posterior probability)}

Red numbers: time estimates ( $\mathrm{Cl}$ 95\%)

\section{s

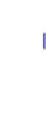

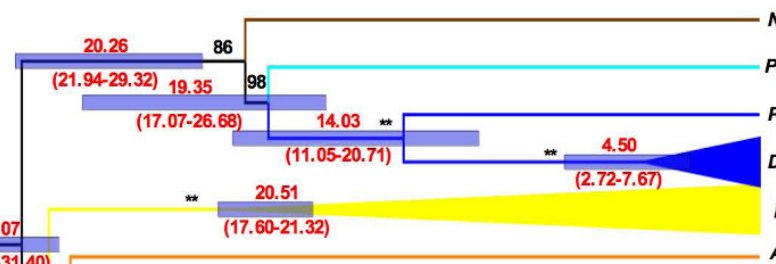

Notemigonus crysoleucas (Lineage I)

Pseudophoxinus egridiri (Lineage $\mathrm{XI}$ )

Pelasgus (Lineage XIII)

Delminichthys (Lineage XI)

Leuciscus (Lineage $\mathrm{X}$ )

Albumoides (Lineage IX)

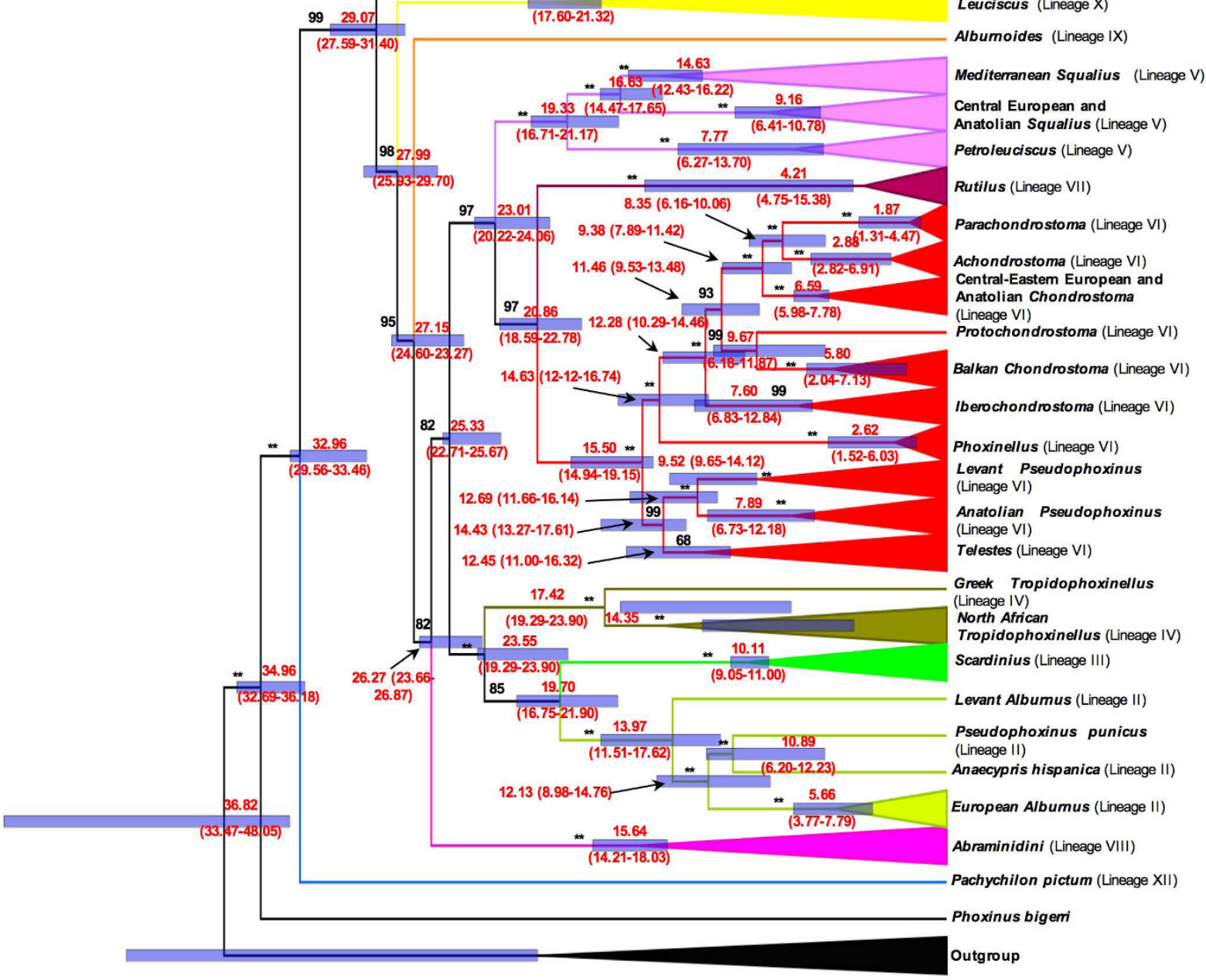

Figure 8 Timing of the major cladogenetic events in leuciscin lineages based on a relaxed molecular clock and in all-genes data set Black numbers represent posterior probability values for BI (** symbol means a value of posterior probability equal to 100). Red numbers

represent divergence times and their HPD 95\% confidence intervals.

accuracy resolution of their phylogenetic framework, and subsequently of their evolutionary history. We have based our phylogenetic discussion in the all-genes topology, which was the most solved and supported tree and summarizes the information of all analyzed genes.

Although some studies have tried to explain the phylogenetic relationships of Mediterranean leuciscins $[4,5,18,37,43,63,64]$, this study is the first molecular approximation to the phylogenetic placement of the three very poorly studied, small size North African Pseudophoxinus species: P. callensis, P. chaignoni and $P$. punicus. We have demonstrated here that none of this three species belong to the real genus Pseudophoxinus. Morphological approaches have already hypothesized a close relationship among $P$. callensis and $P$. chaignoni in relation with $P$. punicus [72]. Our molecular phylogeny corroborate this later affirmation, and whereas $P$. callensis and $P$. chaignoni were closely related, and in turn clustered with the genus Tropidophoxinellus, P. punicus was nested within the Alburnus and Leucaspius group. The phylogenetic positions of the North African species P. punicus and the genera Leucaspius and Anaecypris strongly suggest that these species belong to the lineage of Alburnus. The inclusion of these genera turns into 
paraphyletic the genus Alburnus. For this reason, this issue opens the question about whether the group formed by Alburnus baliki, A. orontis and A. sellal from Anatolia and Levant should represent an independent genus or if the monotypic miniature Anaecypris and Leucaspius should be included into Alburnus. The inclusion of $P$. punicus into the Alburnus lineage has been already proposed based on morphology [72,73], as well as previous morphological $[18,73]$ and molecular studies [5] have already hypothesized a close relationship of Anaecypris and Leucaspius with Alburnus. Moreover, as other dwarf leuciscine, Anaecypris also have been placed in Pseudophoxinus or Phoxinellus by some authors $[74,75]$. As in other small sized and specialized cyprinids as the Leuciscinae Delminichthys [63] and Pelasgus [2] or the Rasborinae Paedocypris [23], synapomorphic characters seem to have been overshadowed by morphological changed connected to miniaturization. However, further specific studies are required to solve these questions. In turn, P. callensis and P. chaignoni are here transferred provisionally to the genus Tropidophoxinellus (See Table 3).

The real genus Pseudophoxinus (type species $P$. zeregi) comprises the Anatolian and Levant species, which are clustered in the same lineage that Telestes (its sister group), Phoxinellus and the six new genera described for the former genus Chondrostoma s. l.: Achondrostoma, Chondrostoma, Iberochondrostoma, Parachondrostoma, Protochondrostoma and Pseudochondrostoma [64]. Within the Anatolian Pseudophoxinus two well-differentiated groups are recognized: one of them is the group formed by the complex of species inhabiting Central Anatolia ( $P$. alii, $P$. anatolicus, $P$. antalyae, $P$. battalgilae, P. crassus, P. elizavetae, P. evliyae, P. fahettini, P. ninae and one possibly undescribed species) and the other one from the Levant ( $P$. firati, P. kervillei, P. zeregi and P. zekayi). Relationships of Pseudophoxinus were not in agreement with morphological studies [76,77].

We also demonstrate here that $P$. egridiri forms a single group related to the Delminichtys-Pelasgus lineage instead of the rest of Pseudophoxinus species. The hypothesis that $P$. egridiri is not related to Pseudophoxinus was already proposed and suspicions that it might be more related to the genus Phoxinus have been formulated [78]. However, our data rejected this hypothesis and demonstrated that $P$. egridiri constitutes an independent phylogenetic lineage. All the species of Delminichthys-Pelasgus lineage are dwarf cyprinids mostly characterized by reductive traits but also have some own synapomorphic characters $[63,76]$. They have been erroneously included in the genus Pseudophoxinus or Phoxinellus $[2,63,79]$. Indeed, Pseudophoxinus was considered to be a subgenus of Phoxinellus for many decades [76].
The genus Telestes is closely related to the main group of Pseudophoxinus and we also support the position of Telestes croaticus, T. fontinalis and T. metohiensis into this genus as were previously pointed out [63]. These species were previously placed in the genus Phoxinellus [79].

The genus Squalius is widely distributed throughout Europe and is highly diversified in the Mediterranean area and three groups have been identified within this genus [32]: A Mediterranean group composed of small species from southern Spain, Central Italy, Southern Greece and the Balkans; an Euroasiatic group that is widely distributed throughout central-east Europe, Asia and the north of Mediterranean area and the Parathethys group, which includes species around the Black sea and Anatolia. Our phylogeny supports these groups, but we have complemented the taxonomical sampling, finding that S. illyricus, S. microlepis, S. svallize and $S$. tenellus also are included within the Mediterranean group reported by Sanjur et al. [32], as well as some Anatolian species in the Euroasiatic group. Furthermore, within the Mediterranean group a geographical structure is observed: an Iberian subgroup, a second Italo-Adriatic subgroup, and a third Greek subgroup (Peloponnesus), which is not found in the "S. cephalus group". As same as Chondrostoma s. $l$. phylogenetic relationships between all of these subgroups were not solved, showing basal politomies rather than bifurcating relationships. Concerning to "Squalius cephalus" complex, an underestimation on the diversity of this group is observed, a further taxonomic review is required, especially in Euphrates drainage. In contrast to the remaining Squalius species, "S. cephalus" complex did not show a geographical structure; thus, Greek Squalius species did not form a monophyletic group due to Iberian S. laietanus was closer to Greek S. orpheus [5,32,37] and Adriatic $S$. squalus was the sister group of Greek S. prespensis. However, phylogenetic relationships within Greek Squalius were in agreement with allozymic [10] and mitochondrial [80] previous studies.

The genus Petroleuciscus (the Squalius Paratethys group recognized by Sanjur et al. [32]) comprises six poorly known species: $P$. borysthenicus (type species), $P$. kurui, $P$. smyrnaeus, $P$. persidis, $P$. squaliusculus and $P$. ulanus [81]. This study represents the first molecular approach that takes into account three species of Petroleuciscus. Petroleuciscus turn out to represent a group of unrelated taxa. Thus, Petroleuciscus borysthenicus and $P$. smyrnaeus are two closely related species from the Aegean and Black sea basins with relationships to the genera Ladygesocypris and Squalius. Interestingly, Leuciscus aphipsi from the northern Caucasus also belongs to this group, being a morphologically very unspecialized species with still many plesiomorphic characters 
Table 3 Taxonomy of subfamily Leuciscinae based on the phylogenetic results obtained in this study and lineages that need further review

\begin{tabular}{ll}
\hline Previous Taxonomy & Proposed taxonomy after this study \\
\hline Genus Notemigonus (Lineage I) & N. crysoleucas \\
\hline N. crysoleucas [152] &
\end{tabular}

\section{Genus Alburnus (Lineage II)}

Al. alburnus [2]; Al. arborella [2]; Al. belvica [2]; Al. demiri [153]; Al. escherichii [154]; Al. filippii [154]; Al. hohenackeri [2]; Al. macedonicus [2]; Al. mento [2]; Al. orontis [154]; Al. sarmaticus [2]; Al. thessalicus [2]

Alburnus populations from Kizilimark R.

Without changes

Alburnus populations from Stryrmon R.

Alburnus sp. 1

Alburnus sp. 2

Al. sellal [154]; Al. baliki [155]; Al. kotschyi [156]; Al. orontis [154]

A new genus should be described for these species to avoid the paraphyletic status of Alburnus (Type species: A. alburnus)

Genus Anaecypris (Lineage II)

An. hispanica [2] An. Hispanica

Genus Leucaspius (Lineage II)

L. delineatus [2]

L. delineatus

Genus Pseudophoxinus (Lineage II)

A new genus should be described for this species because real

Ps. punicus [157] Pseudophoxinus (type species P. zeregi) belong to a different lineage

Genus Scardinius (Lineage III)

Sc. acarnanicus [2]; Sc. erythrophthalmus [2]; Sc. graecus [2]; Sc. hesperidicus [2]; Without changes

Sc. plotizza [2]; Sc. scardafa [2]

Genus Tropidophoxinellus (Lineage IV)

Tr. hellenicus [2]; Tr. spartiaticus [2]

Genus Pseudophoxinellus

PS. callensis [77]

Ps. chaignoni [77]

Genus Petroleuciscus (Lineage V)

Pe. borysthenicus [2], Pe. smyrnaeus [2]

Genus Squalius

Sq. aphipsi [2]

\section{Genus Ladigesocypris (Lineage V)}

La. ghigii [2]

La. irideus [2]

\section{Genus Squalius (Lineage V)}

Sq. albus [2]; Sq. aradensis [2]; Sq. carolitertii [2]; Sq. castellanus [158]; Sq. cephalus [2]; Sq. illyricus [2]; Sq. keadicus [2]; Sq. kosswigi [159]; Sq. kottelati [159]; Sq. laietanus [2]; Sq. lepidus [2]; Sq. lucumonis [2]; Sq. malacitanus [2]; Sq. microlepis [2]; Sq. moreoticus [2]; Sq. orientalis [2]; Sq. orpheus [2]; Sq. pamvoticus [2]; Sq. peloponensis [2]; Sq. prespensis [2]; Sq. pyrenaicus [2]; Sq. squalus [2]; Sq. svallize [2]; Sq. tenellus [2]; Sq. torgalensis [2]; Sq. valentinus [2]; Sq. vardarense [2]; Sq. zrmanjae [2]

Squalius populations from Southern Spain

Squalius populations from Aksheir L. Turkey

Squalius populations from Euphrates drainage

Squalius populations from Rama L. BiH

Squalius populations from Manikiotico R.

\section{Genus Achondrostoma (Lineage VI)}

Ach. arcasii [2]; Ach. occidentale [2]; Ach. salmantinum [158]; Ach. oligolepis [2] Achondrostoma populations from NE Spain

\section{Genus Chondrostoma (Lineage VI)}

Ch. angorense [160]; Ch. cyri [160]; Ch. holmwoodii [161]; Ch. knerii [2]; Ch. meandrense [160]; Ch. nasus [2]; Ch. oxyrhynchum [2]; Ch. phoxinus [2]; Ch. prespensis [2]; Ch. regium [160]; Ch. soetta [2]; Ch. vardarense [2] Ch. olisiponensis [162]

\section{Genus Tropidophoxinellus}

Without Changes

Tr. callensis

Tr. chaignoni

Without changes

Genus Petroleuciscus

Pe. aphipsi

Necessary to analyze all species considered as belonging to Petroleuciscus (P. kurui, P. squaliusculus, P. ulanus)

\section{Genus Squalius}

Sq. ghigii

Sq. irideus

Without changes

Squalius sp

Squalius sp_Euphrates

Squalius sp_Aksheir

Squalius aff. vardarensis

Squalius cf. orpheus

\section{Achondrostoma}

Without changes

Achondrostoma sp

Without changes

Iberochondrostoma olisiponensis 
Table 3 Taxonomy of subfamily Leuciscinae based on the phylogenetic results obtained in this study and lineages that need further review (Continued)

Genus Iberochondrostoma (Lineage VI)

Ib. almacai [2];i Ib. lemmingii [2]; Ib. Iusitanicum [2]; Ib. oretanum [2]

Without changes

Genus Parachondrostoma (Lineage VI)

Pa. arrigonis [2]; Pa. miegii [2]; Pa. toxostoma [2]; Pa. turiense [2]

Without changes

Genus Phoxinellus (Lineage VI)

Ph. alepidotus [2]; Ph. dalmaticus [2]; Ph. pseudalepidotus [2]

Without changes

\section{Genus Protochondrostoma (Lineage VI)}

Pr. genei [2]

Without changes

\section{Genus Pseudochondrostoma (Lineage VI)}

Pse. duriense [2]; Pse. polylepis [2]; Pse. willkommii [2]

Without changes

\section{Genus Pseudophoxinus (Lineage VI)}

PS. alii [77]; PS. anatolicus [154]; PS. antalyae [154]; PS. battalgilae [154]; PS.

crassus [154]; PS. elizavetae [77]; Ps. evliyae [163]; PS. fahrettini [163]; Ps. firati

Without changes

[77]; Ps. kervillei [164]; PS. ninae [63]; Ps. zekayi [77]; Ps. zeregi [165]

Pseudophoxinus populations from Eflatun Pinari spring. Turkey

Pseudophoxinus sp_EflatunPinari

\section{Genus Telestes (Lineage VI)}

Te. alfiensis [63]; Te. beoticus [2]; Te. croaticus [2]; Te. fontinalis [2]; Te.

metohiensis [2]; Te. montenegrinus [2]; Te. muticellus [2]; Te. pleurobipunctatus

[2];

Te. polylepis [2]; Te. souffia [2]; Te. turskyi [2]; Te. ukliva [2]

Telestes populations from Dreznica. Croatia

\section{Genus Rutilus (Lineage VII)}

Ru. aula [2]; Ru. basak [2]; Ru. frisii [2]; Ru. heckeli [2]; Ru. ohridanus [2]; Ru. panosi [2]; Ru. pigus [2]; Ru. prespensis [2]; Ru. rubilio [2]; Ru. rutilus [2]; $R u$. ylikiensis [2]

Genus Abramis (Lineage VIII)

Ab. brama [2]

Genus Acanthobrama (Lineage VIII)

Without changes

Telestes sp.

AC lissneri [166]: Ac marmid [154]

Genus Acanthalburnus (Lineage VIII)

Aca. microlepis [154]

Without changes

Genus Petroleuciscus (Lineage VIII)

Pe. persidis [167]

Without changes

Genus Ballerus (Lineage VIII)

Ba. ballerus [2]; Ba. sapa [2]

Genus Acanthobrama

Genus Acanthobrar
Without changes

Genus Blicca (Lineage VIII)

Bl. bjoerkna [2]

Ac. microlepis

Ac. Persidis

\section{Genus Mirogrex (Lineage VIII)}

Mi. terrasanctae [164]

Genus Vimba (Lineage VIII)

Without changes

Vi. melanops [2]; Vi. vimba [2]

Without changes

\section{Genus Acanthobrama}

Ac. mirabilis [154] (Vi. Vimba by synonymy [6])

\section{Genus Alburnoides (Lineage IX)}

Alb. bipunctatus [2]; Alb. prespensis [2]; Alb. bipunctatus [2]

Genus Leuciscus (Lineage $\mathbf{X}$ )

Without changes

Genus Vimba

Without changes

Le. idus [2]; Le. latus [167]; Le. leuciscus [2]; Le. schdmidti [46]; Le. walecki [168]

V. mirabilis

\section{Genus Aspius (Lineage $\mathrm{X}$ )}

As. aspius [2];

Without changes

As. vorax [2]

Genus Leuciscus

Without changes

Genus Pseudophoxinus (Lineage $\mathrm{XI}$ )

P. egridiri [154]

Le. aspius

Le. vorax

A new genus should be described for this species because real Pseudophoxinus (type species $P$. zeregi) belong to a different lineage 
Table 3 Taxonomy of subfamily Leuciscinae based on the phylogenetic results obtained in this study and lineages that need further review (Continued)

\begin{tabular}{|c|c|}
\hline Genus Pachychilon (Lineage XII) & \\
\hline Pac. macedonicum [2]; Pac. pictum [2] & Without changes \\
\hline Genus Delminichthys (Lineage XII) & \\
\hline D. adpersus [2]; D. ghetaldii [2]; D. jadovensis [2]; D. krbavensis [2] & Without changes \\
\hline Genus Pelasgus (Lineage XIII) & \\
\hline $\begin{array}{l}\text { P. laconicus [2]; P. marathonicus [2]; P. minutus [2]; P. prespensis [2]; P. } \\
\text { stymphalicus [2]; P. thesproticus [2] }\end{array}$ & Without changes \\
\hline Genus Pelecus (Lineage XIV) & \\
\hline P. cultratus [2] & Without changes \\
\hline
\end{tabular}

$[82,83]$. Although this species was transferred from the genus Leuciscus into the genus Squalius [2,84], our outcome demonstrates that it is more related to the genus Petroleuciscus than to Squalius and it is therefore transferred to Petroleuciscus here (See table 3). Iranian Petroleuciscus persidis was initially described as a species of Pseudophoxinus [85], later transferred to the genus Leuciscus [44] suspected to be related to P. smyrnaeus (former considered as L. smyrnaeus) [86] and then included in Petroleuciscus [81]. These relationships are inconsistent with our molecular data, which strongly support close affinities of $P$. persidis with the genus Acanthobrama, also pointing on the difficulties of morphological characterization of miniaturized cyprinids [23,63]. Therefore, this species is transferred to Acanthobrama as A. persidis (See table 3). Furthermore, our data support the synonymization of the genus Acanthalburnus with Acanthobrama, both genera just distinguished by the two $v s$. one rows of pharyngeal teeth [46]. Our results demonstrate also that both species of the highly specialized, predatory genus Aspius belong to Leuciscus. Therefore, these species are transferred to Leuciscus as $L$. aspius and $L$. vorax (See table 3 ).

The position of the genus Ladygesocypris (L. ghigii and $L$. irideus) nested in or close to the Squalius clade was already reported for mitochondrial data $[6,32]$ and here is also supported by nuclear markers. Ladygesocypris was recently included into the genus Pseudophoxinus [77], a hypothesis that has not molecular support. However, its transfer to Squalius is supported by our data (See table 3).

With regards to Scardinius, this genus have been considered the sister group of Tropidophoxinellus [5,87] but a close phylogenetic relationship among Scardinius and Alburnus has also been hypothesized [5,18]. Our phylogeny strongly supported the sister relationship among Scardinius and Tropidophoxinellus more than among Scardinius and Alburnus, independently of the North African species Pseudophoxinus chaignoni and P. callensis belong to the genus Tropidophoxinellus or not. Our nuclear phylogeny showed a low support for a relationship among Scardinius and Rutilus, as suspected already by morphological characters [14]. Whereas mitochondrial cyt $b$ analysis grouped together the lineages of Scardinius, Tropidophoxinellus-Pseudophoxinus callensis-P.chaignoni (transferred here to Tropidophoxinellus callensis and T. chaignoni) and Alburnus-AnaecyprisLeucaspius-Pseudophoxinus punicus, basal relationships among these lineages were not solved with COxI and nuclear markers, probably due to the slower evolutionary rate of these genes respect to cyt $b$ one. However, combined data matrix (all genes) analysis recovered this relationship. Within the genus Scardinius, our data support some recognized species [2]. S. erythrophthalmus is a Central and Eastern European species, S. scardafa endemic to Lake Scanno in Central Italy $[62,88]$ is closely related to $S$. hesperidicus, as has been previously established $[62,89]$. Scardinius plotizza from the Dalmatian River Neretva constituted an independent and highly supported clade.

\section{Biogeography \\ Divergence time estimates and general biogeographical patterns}

To decipher evolutionary and biogeographical patterns in the Mediterranean leuciscins, the different authors have calibrated a molecular clock for the cytochrome $b$ gene using fossil or geological data $[5,7,20,37,43,90]$. Based on fossil calibration, we obtained an evolutionary rate of $0.4 \%$ divergence per lineage per million years ( $0.8 \%$ per pairwise comparison) for cytochrome $b$, which differs from previous estimates [5,90], and is slightly slower than formerly proposed for North American cyprinids based on fossil data $(0.5 \%$ per lineage per million year) [91]. The present study is the first to use nuclear markers to estimate the main historical processes that gave rise to the current phylogeny and distribution of the Mediterranean leuciscine lineages. The average evolutionary rate obtained here was $0.2 \%$ per lineage per million years for the combined dataset (cytochrome $b$, COxI, RAG1 and S7) (0.4\% per pairwise comparison). Notwithstanding, estimated divergence times 
were congruent to those predicted by the cytochrome $b$ gene (not shown) and fell within the same confidence intervals. However, credibility intervals of the combined dataset (i.e. more informative sites in the analysis) were narrower, suggesting that the combination of several markers may improve the results [92].

The complex paleogeography of the Mediterranean region, with migrating island arcs, fragmenting tectonic belts and other plate tectonic events have contributed to the formation of a reticulate biogeographical pattern in which the current leuciscine groups formed as geographical barriers appeared and disappeared through time. This reticulate pattern is, however, not reflected by a congruent biogeographical pattern in leuciscine relationships based on sister groups within each evolutionary lineage.

Origin of leuciscins in Mediterranean inland waters: birth of the Paratethys

According to our molecular evolutionary rate based on a relaxed molecular clock and all-gene database, the main Mediterranean leuciscine lineages arose and diversified in the Oligocene period (Figure 8). In the context of the widely accepted origin of cyprinids in Asia, our data do not contradict the north-dispersal model of the first cyprinid colonization of northern Europe across Siberia $[34,35]$, when the Turgai Straits were closed around the Eocene-Oligocene boundary (approximately 34 mya; Figure 9A) and strongly support a gradual colonization of Mediterranean region since Oligocene, as have been recently stated [93]. As the fossil record shows, this first cyprinid colonization event involved phoxinin and gobionin lineages [94,95]. However, according to our data, the presence of old leuciscins in the Balkan/Anatolia area of possible Southwest Asian origin could be explained by the emergence of a huge Balkanian-Anatolian-Iranian landmass in the Early Oligocene (33 mya) [96]. Continental collisions and tectonic movements along the AlpineHimalayan orogenic belt, which led to the separation of the Paratethys Epicontinental Sea from the Tethys Ocean, drove this event. We therefore propose an initial leuciscine colonization of Europe from southwestern Asia via the Balkanian-Anatolian-Iranian landmass at the beginning of the Early Oligocene (Figure 9B), which precisely matches the initial splitting of the most basal leuciscine lineages (XI, XII and XIII) from the remaining leuciscins in 32.9 mya (CI 95\% 29.6-33.5).

Unequivocal fossil proof of this biogeographic hypothesis is hampered by the fact that Oligocene freshwater deposits from the Balkanian-Anatolian-Iranian landmass are scarce and not well studied. The oldest fossils that could be ascribed to the Leuciscinae have been recovered in central Anatolia (Table 4) and have been dated around the Oligocene-Miocene boundary $[97,98]$. This material consists of isolated pharyngeal teeth and otoliths for which a leuciscine relationship is possible, but not certain.

Vicariant events promoting leuciscine diversification in the Oligocene: Paratethys isolation and reconnection

During most of the Early Oligocene (Solenovian regional stage), the Tethys and Paratethys Seas remained isolated by the Balkanian-Anatolian-Iranian landmass. Marine connections fragmented this landmass around 28 mya into the huge Balkanian and Anatolian islands [96]. This vicariant event was probably responsible for splitting of the ancient Balkan-Anatolian lineages around the EarlyLate Oligocene transition (29.1 mya, CI 95\% 27.6-31.4). This main Late Oligocene paleogeographic (Figure 9C) setting persisted until the early Burdigalian 20 to 19 mya.

By the end of the Oligocene (23 mya) half of all leuciscin lineages (7 out of 14) (Figure 8) had become established, indicating their rapid diversification during the Late Oligocene. During this time, leuciscine fossils are unknown from the European mainland and we hypothesize that this diversification occurred on the Balkanian-Anatolian-Iranian archipelago. Geodynamic data substantiating vicariant events in the Late Oligocene are rare from this area. For the time being, it may be speculated that karstic landscapes, similar to those found in this region today, could have facilitated the geographical isolation and speciation process.

Vicariant events promoting leuciscine diversification in the Early-Middle Miocene: the Alpine Orogeny, Dinarid Lake systems and Gomphotherium landbridge

More recent paleogeographical events support the splitting of some leuciscine groups in the Early-Middle Miocene, from 20 to 12 mya, giving rise to most of the current genera. This period coincides with a major period in the Alpine orogeny, including the closing of the Slovenian corridor, the extrusion and uplift of the Eastern Alps and substantial microplate rotations and basin inversion in the Pannonian-Carpathian-Dinaric realm [99-104].

The Slovenian corridor, a marine connection between the Tethys and Paratethys Seas separated the BalkanianAnatolian landmass from the rest of Europe during the Oligocene and earliest Miocene. This gateway closed around 20 mya [105] and probably enabled the first colonization of Central Europe by leuciscins from the Balkanian-Anatolian landmass (Figure 9D). This view is supported by fossils like the oldest European leuciscins in sediments from about 19 mya in Germany related to Pseudophoxinus and Delminichthys $[94,106,107]$ and from 19-18 mya old fossils of Aspius and "Alburnus" $[108,109]$ in the Czech Republic. These paleontological data fit the start of diversification of leuciscins such as Aspius (20.5 mya, CI 95\% 17.6-21.3) or Alburnus lineages (19.7 mya, CI 95\% 16.7-21.9). 


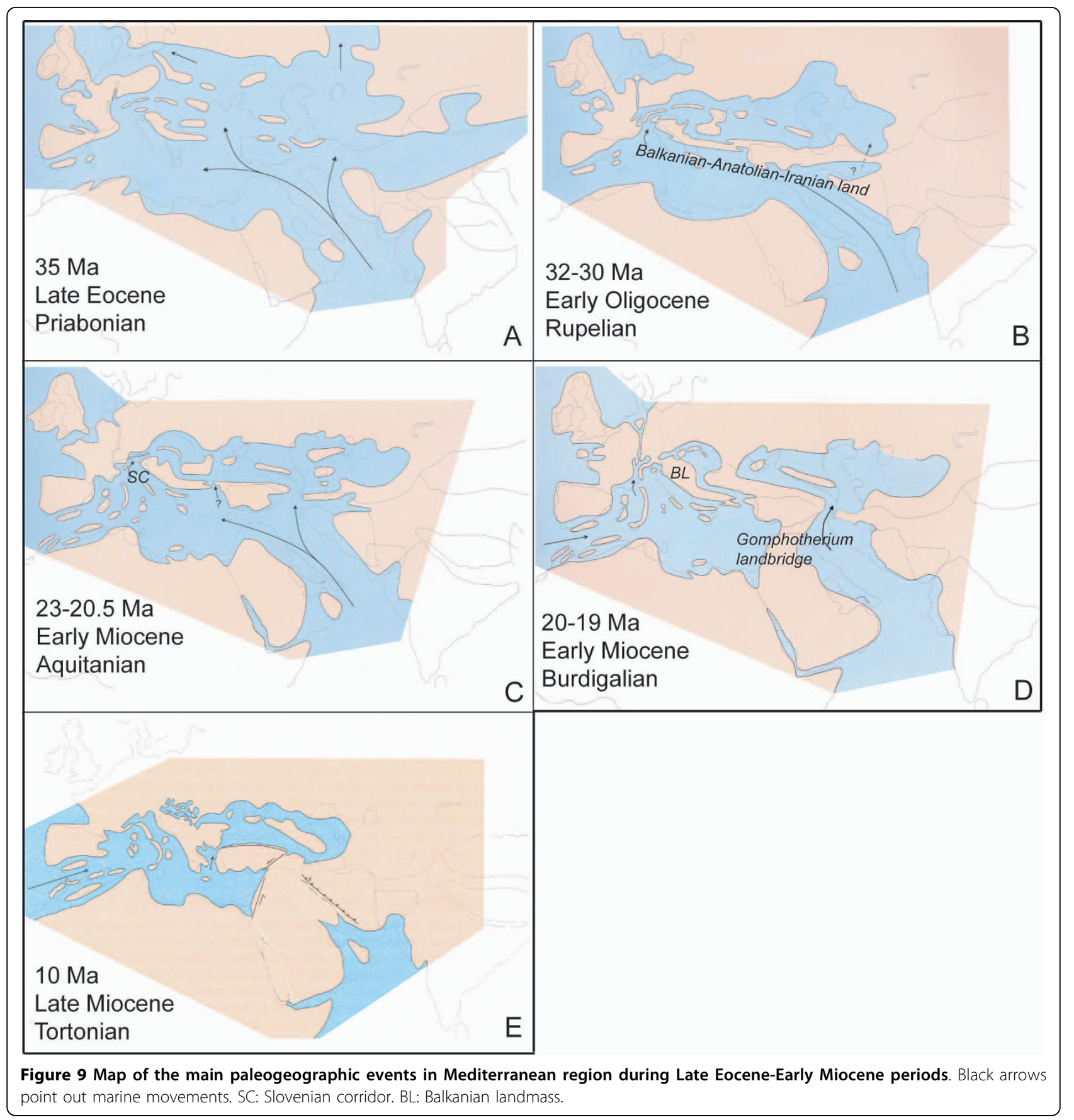

The Alpine orogeny similarly affected the leuciscine ichthyofauna of the Mediterranean Peninsulas. Thus, in the Iberian Peninsula, the Pyrenees promoted the isolation of Iberian freshwater fishes during the Miocene period when they took on their current form [110-112]. Indeed, all leuciscins from this region are endemic except Squalius laietanus, which also inhabits southern France. Thus, the Iberian Squalius must have split from the Balkan and Italian Squalius 14.6 mya (CI 95\% 10.914.9). In turn, the endemic genera Achondrostoma,
Iberochondrostoma, Parachondrostoma and Pseudochondrostoma split from the genus Chondrostoma 9.4 mya (CI 95\% 7.9-11.4). The Pyrenees may have also constituted a vicariant barrier between the European and Iberian Alburnine (ancestors of Anaecypris, Alburnus and/or Leucaspius), splitting 12.1 mya (CI 95\% 9-14.8). This timing of the origin of Iberian Leuciscinae lineages is congruent with the results of previous studies $[43,64]$.

In the Apennine Peninsula, the Alpine orogeny may have also played an important role in isolating its 
Table 4 First fossil occurrence of Leuciscinae in Europe

\begin{tabular}{|c|c|c|c|c|}
\hline FOSSIL TAXON & RECENT RELATIVES & LOCALITY & $\begin{array}{l}\text { AGE } \\
(\mathrm{Ma})\end{array}$ & REFERENCE \\
\hline Leuciscinae indet. & Leuciscinae & Kilcak (Eskikilcak), central Anatolia & $\begin{array}{l}23.5- \\
24.5\end{array}$ & [150] \\
\hline $\begin{array}{l}\text { Palaeoleuciscus } \\
\text { dietrichsbergensis }\end{array}$ & Pseudophoxinus, Delminichthys & $\begin{array}{l}\text { Dietrichsberg, Rhön mountains, } \\
\text { Germany }\end{array}$ & 19 & {$[94,106,107]$} \\
\hline Aspius laubei & Aspius aspius & $\begin{array}{l}\text { North Bohemian Browncoal Basin, } \\
\text { Czech Republic }\end{array}$ & $18-19$ & {$[108,109]$} \\
\hline Alburnus steindachneri & Alburnus chalcoides species group & $\begin{array}{l}\text { North Bohemian Browncoal Basin, } \\
\text { Czech Republic }\end{array}$ & $18-19$ & {$[108,109]$} \\
\hline Leuciscus sp. & Leuciscus s. str. & Sofca, Turkey & $11-13$ & $\begin{array}{l}\text { Böhme unpubl., } \\
\text { [150] }\end{array}$ \\
\hline Scardinius haveri & Scardinius ssp. & Vösendorf, Austria & 10.3 & [151] \\
\hline Leuciscus aff. cephalus & Squalius cephalus & Lava 2, Greece & 6.56 & $\begin{array}{l}\text { Böhme unpubl., } \\
\text { [150] }\end{array}$ \\
\hline "Chondrostoma" sp. & $\begin{array}{l}\text { Achondrostoma, Pseudochondrostoma, Iberochondrostoma, } \\
\text { Parachondtrostoma }\end{array}$ & Tolosa, Spain & $\begin{array}{l}5.33- \\
5.8\end{array}$ & $\begin{array}{l}\text { Böhme unpubl., } \\
\text { [150] }\end{array}$ \\
\hline $\begin{array}{l}\text { Scardinius cf. } \\
\text { erythrophtalmus }\end{array}$ & Scardinius erythrophthalmus & Ptolemais 1A, Greece & 5.31 & $\begin{array}{l}\text { Böhme unpubl., } \\
\text { [150] }\end{array}$ \\
\hline Aspius sp. & Aspius aspius & Ptolemais 1B, Greece & 5.29 & $\begin{array}{l}\text { Böhme unpubl., } \\
{[150]}\end{array}$ \\
\hline Chondrostoma sp. & Chondrostoma ssp. & Ptolemais 2, Greece & 5.21 & $\begin{array}{l}\text { Böhme unpubl., } \\
{[150]}\end{array}$ \\
\hline Rutilus sp. & Rutilus ssp. & Tchelopetchene, Sofia Basin, Bulgaria & $4-5.3$ & $\begin{array}{l}\text { Böhme unpubl., } \\
\text { [150] }\end{array}$ \\
\hline
\end{tabular}

ichthyofauna. Most of Italy was below sea level during most of the Miocene [113] and it is consequently believed that the Italian ichthyofauna is of a more recent origin than that of the remaining Mediterranean Peninsulas. Although dispersion during the lacustrine phase of the Mediterranean Sea has been suggested as the origin of the Italian ichthyofauna [38], our data point to an older origin, probably related to the lateral tectonic extrusion of the eastern Alps between 17 and 11 mya that isolated Italian taxa from north and central Europe. The role of the eastern Alps as a barrier to Italian and Adriatic freshwater ichthyofauna has been previously established $[114,115]$. This is the case for Protochondrostoma 11.5 mya (CI 95\% 9.5-13.5), or some Rutilus, which according to our mitochondrial data (figure not shown), split 9.7 mya (CI 95\% 6.2-10.6) into $R$. rubilio and 13.2 mya (CI 95\% 9.4-15.1) into $R$. pigus. This is the only case in which mitochondrial information has been used to disscus date estimation. This can be explained due to we only incorporated a few representatives of each genera to perform all-gene molecular clock analysis and none of these species have been include on all-gene dataset. However, the knowledge of this splitting date for species such as Protochondrostoma genei or Rutilus rubilio and $R$. pigus is crucial to show the effect of Alps as a barrier for Italian and Adriatic freshwater icthyofauna.

In the Balkan Peninsula, and especially in the Dalmatian area, huge lake systems existed between 17 and 15 mya during the late early Miocene and early Middle Miocene (e.g. Dinaric Lake system, Lake Skopje; [116]). The fragmentation or disappearance of these lakes could have enhanced isolation and promoted speciation. Such is the case of Delminichthys, which split from Pelasgus in approximately 14 mya (CI 95\% 11.0- 20.7). This dating is close to previously estimates (13 mya; [63]) and also coincides with the splitting of Chondrostoma s.l. from its sister group Phoxinellus isolated in Dalmatia 14.6 mya (CI 95\% 12.1-16.7). Subsequent to this period of lakes, the region experienced the onset of compressional tectonic stress in the late Serravallian around 12.5 mya, initiating a period of uplift of the Dinaric Alps [117]. This orogenic event could have generated barriers for the Dalmatian Chondrostoma, Squalius and Telestes, which split approximately 9.7 mya (CI 95\% 6.2-11.9), 9.2 mya (CI 95\% 5-10.1) and 12.4 mya (CI 95\% 11-16.3) respectively.

Another important vicariant event between the Greek and North African Tropidophoxinellus took place in the Early Miocene in 17.4 mya (CI 95\% 7.9-16.6), indicating colonization of Africa by leuciscins well before the Messinian salinity crisis. This finding rejects the later hypothesis of "Lago Mare dispersal" [38] for the colonization of North Africa by leuciscins, which would explain the colonization of this region due to dispersion during the lacustrine phase of the Mediterranean Sea (Messinian salinity crisis). The most plausible 
explanation for vicariance between the Peloponessus and Magreb area is the migration of common ancestors of Tropidophoxinellus from the Balkanian-Anatolian landmass into North Africa via the Gomphotherium landbridge established in West Asia around 19 mya (Figure 9D). This landbridge separated the Tethyan Ocean into the Mediterranean Sea and Indian Ocean and allowed the first continental exchange between Eurasian and African mammals and reptiles $[118,119]$ and the first colonization of Africa by barbin cyprinids ([120]; Böhme unpublished data). Despite fossil leuciscins being as yet unknown from the African Miocene, the data presented here suggest that leuciscins probably took part in this Early Miocene dispersal event.

Of special biogeographic interest is the sister-group relationship between Notemigonus crysoleucas, the only North American leuciscine species, and the old Balkanian-Anatolian Pseudophoxinus egridiri/Pelasgus/Delminichthys lineages, which separated according to our data around 20.3 mya (Figure 8 ). However this relationship has to be considered with caution due to its relatively low support (posterior probability equal to 86). As stated above, a possible sister taxon of the Pseudophoxinus egridiri/Pelasgus/Delminichthys lineages, the fossil genus Palaeoleuciscus, made its oldest fossil appearance in 19 mya old sediments of central Europe, indicating a transatlantic biogeographic connection. Interestingly, an Early Miocene transatlantic colonization of North America by cyprinids was already speculated by Böhme [94] in the context of the paleobiogeography of phoxinins. This author demonstrates a sister-group relationship between the central European Oligocene phoxinin Palaeorutilus and the eastern North American Creek Chub clade of phoxinins. The data presented here further support such an idea, and may indicate that eastern North America was colonized during Early Miocene times via a transatlantic route by the ancestors of the leuciscin Notemigonus (a species related to Palaeoleuciscus) and the Creek Chubs (species related to Palaeorutilus). The paleogeographic details of this hypothesis, however, remain obscure.

\section{Vicariant events promoting leuciscine diversification in the Upper Miocene}

In this period, the opening of the Aegean Sea was an important event for leuciscins (Figure 9E), which is thought to have started in the Late Serravallian about 12 mya [101] and finished during the Tortonian between 10 and 9 mya [121-123]. As a consequence, some groups of Greek and Anatolian leuciscins diversified, such as Squalius ghigii/irideus from Rhodos Island and Southwestern Anatolia and Squalius keadicus from southern Greece. These taxa split 8.7 mya (CI 95\% 713.2). In fact, the paleogeographical history of the
Balkan Peninsula is strongly linked to the paleogeography of Anatolia since both areas were joined in the same landmass and isolated from the rest of Europe during long periods of the Oligocene and Miocene.

The North African Pseudophoxinus punicus splits near the Middle-Late Miocene boundary; also well before the Messinian salinity crisis. Two possible vicariant barriers could explain its distribution: the opening of the Gibraltar Straits (splitting of Iberian Anaecypris), which has been recognized as a geographical barrier for some groups [124], or the opening of the Channel of Sicily (splitting of European Alburnus or Leucaspius). However, both the Gibraltar Straits and the Sicily Channel formed at the Miocene/Pliocene boundary at the end of the Messinian salinity crisis $[40,125]$ and our estimated divergence time for $P$. punicus is earlier than this date (10.9 mya, CI 95\% 6.2-12.2). The vicariant event leading to the separation of Pseudophoxinus punicus therefore remains unclear.

\section{The Messinian}

The Messinian has been postulated as the time of diversification of Mediterranean cyprinids. Hence, the Lago Mare stage of the Mediterranean would have enabled the massive dispersion of cyprinids across the basin. The later return to marine conditions could have meant a fast speciation process for cyprinids. This may be reflected in the deep polytomies found in the phylogeny. Thus, some authors have defended the Lago Mare hypothesis [38] based on non-resolved polytomies among the main clades $[7,42,54]$. However, our phylogeny does not show a critical point of speciation around 5 mya. These processes took place gradually over time, but preclude any massive dispersal and speciation during the Messinian period, as has been proven for Squalius and Chondrostoma s.l. $[37,43,64]$. Fossils of the Spanish genera (Achondrostoma, Iberochondrostoma, Parachondrostoma, Pseudochondrostoma) are recorded first in the late Messinian (Table 4), which may indicate dispersal of their ancestors during the Messinian Lago Mare stage.

\section{Pliocene and Pleistocene}

The beginning of the Pliocene is characterized by a rise in humidity in the Mediterranean region [126], which may have promoted the diversification of Leuciscinae genera in different Mediterranean Peninsulas, through the possible colonization of newly established freshwater environments after the Messinian salinity crisis. In the Iberian Peninsula, tectonic disconnections of presentday Iberian basins took place during the Plio-Pleistocene [127] promoting widespread endorrheism and thus enhancing the process of allopatric speciation, which is reflected in the high species-levels of most Iberian genera except the monotypic genus Anaecypris. In turn, the divergence of some Italian taxa from their Balkanian 
sister-taxa occurred in this period, such as the splitting of Rutilus aula (4.75 mya, CI 95\% 1.91-5.02), and Squalius lucumonis (3.53 mya, CI 95\% 2.13-5.80).

In the Adriatic-Balkanian region, even more recent events explain the great affinities found between the ichthyofauna of northern Italy and northern rivers of the Balkan Peninsula. These similarities reflect recent contact between North Italian and North Adriatic-Balkanian ichthyofauna due to expansion of the Po River during the Last Glacial Maximum as a result of a drop in sea level [128]. This event may have prompted the exchange of many freshwater taxa among Italian and Balkan river systems, and also explains the current distribution of species such as Squalius squalus and similarities found between Chondrostoma soetta and the Dalmatian species Chondrostoma knerii and C. phoxinus. Similar affinities have been described for freshwater fish species from northern Italy and Balkan rivers including Cobitis [129] or Cottus [130] species.

On the other hand, Pleistocene glaciations also played an important role in the current European distribution of the Leuciscinae, and determined a more recent origin of some leuciscine taxa after colonization from glacial refuges such as the Danube basin. However, other rivers of the Black Sea basin could have also acted as a glacial refuge for freshwater ichthyofauna [51]. Some northcentral European representatives of leuciscins share a widespread distribution range: Alburnoides bipunctatus, Alburnus alburnus, Chondrostoma nasus, Rutilus rutilus, Scardinius erythrophthalmus and Squalius cephalus. This pattern can be explained by the homogeneity conferred by glacial refuges [35,131-133]. Thus, secondary recolonization of Western Europe from a Danubian refuge has been postulated for $S$. cephalus [131] and $C$. nasus [34,134]. River captures, river confluences and sea level lowering have been incriminated in the dispersion of these species [131]. Thus, glacial periods promoted the expansion and genetic homogenization of these species across Europe [48,131,135]. Since most central European basins were covered by ice during the Pleistocene, colonization is the most likely mechanism to explain the expansion of these species. However, they could not have reached the Mediterranean Peninsulas because of the transverse alignment of Alpine Mountains, which were well formed in the Pleistocene except in the eastern part of the Balkan Peninsula. This area shows the influence of the Danube basin due to the oblique direction of the Dinaric Alps.

\section{Conclusions}

Mitochondrial and nuclear results demonstrated the existence of fourteen major phylogenetic leuciscine lineages. However, some incongruence was found between mitochondrial and nuclear markers, possibly due to the lack of resolution of deep nodes in nuclear phylogeny as well as their slower evolutionary rate. Combined analysis (mitochondrial + nuclear) recovered the major lineages and increased their support.

With regards to phylogenetic relationships, this study is the first molecular approximation to the phylogenetic placement of North African leuciscine species (P. callensis, $P$. chaignoni, and P. punicus). None of these three species belong to the real genus Pseudophoxinus, as well as $P$. egridiri, and constitute independent lineages. The real genus Pseudophoxinus includes species from Anatolia and Levant. Our phylogeny also demonstrates that the genus Petroleuciscus is polyphyletic and as a result its species involve different leuciscine lineages. It also point out the closer relationship of Squalius aphipsi to Petroleuciscus. As our phylogeny show, the taxonomy of the genera Pseudophoxinus and Petroleuciscus is a matter of controversy because of synapomorphic characters are prone to be overshadowed by morphological changes associated to miniaturization. New insights in the phylogenetic relationships of some Squalius species are showed too, such as some Dalmatian species, as well as the corroboration by nuclear markers of the phylogenetic position of Ladigesocypris ghigii/irideus as closer related to the genus Squalius.

In relation to biogeographical history of Leuciscinae, the present study is the first to use nuclear markers to estimate main historical processes that gave rise to the current phylogeny and distribution of Circum-Mediterranean Leuciscinae. A relaxed molecular clock corroborated the arisen and divergence of the main Leuciscinae lineages during Late Oligocene-Early Miocene. Our data do not contradict the north-dispersal model of the first cyprinid colonization of Northern Europe across Siberia. However, most of the divergence events were older than Lago Mare dispersal model. We proposed an initial colonization of Europe from Southwestern Asia via the Balkanian/Anatolian/Iranian landmass at the beginning of the Early Oligocene, which precisely matches the initial splitting of the most basal leuciscins. Later vicariant events as the Paratethys isolation and later reconnection with Tethys during the Oligocene and the Alpine Orogeny, Dinarid lake systems and Gomphoterium landbridges during Miocene promoted Leuciscinae diversification. Our data also corroborate the colonization of North Africa before the Messinian salinity crisis. In Upper Miocene the opening of Aegean Sea was an important vicariant event for Anatolian and Greek leuciscins. Messinian appears as a stage of gradually Leuciscinae diversification more than a critical point of speciation. The rise of humidity at the beginning of the Pliocene may have promoted the diversification of Leuciscinae genera due to the colonization of newly established freshwater environments. Finally, Pleistocene 
glaciations also played an important role in the current European distribution of some leuciscins.

\section{Methods}

\section{Sampling, DNA extraction, PCR and sequencing}

The complete mitochondrial cytochrome $b$ (total of $1140 \mathrm{bp}$ ) from 321 specimens belonging to 176 species of leusciscins was obtained from Europe, Western Asia, North Africa and North America (Figure 10). Of total individuals, 186 were new sequences for cytochrome $b$ and the remaining sequences were acquired from Genbank. Similarly, 146 individuals were sequenced to obtain a fragment of the mitochondrial Cytochrome oxidase I gene (646 bp). For the nuclear phylogenetic analysis, a subset of 101 individuals was selected from mtDNA lineages and sequenced for both the nuclear genes RAG1 (1473 bp) and the first intron of the ribosomal protein S7 (1112 bp total alignment including gaps). DNA voucher specimens were deposited at the collection of the Museo Nacional de Ciencias Naturales (Madrid, Spain). List of individuals, localities and GenBank Accession numbers are reported in Additional file 1.

For phylogenetic analyses, we rooted the trees with representatives of several cyprinids subfamilies. For this purpose, species such as Gobio gobio (Gobioninae) Rhodeus amarus, $R$. ocellatus and $R$. atremius (Acheilognatinae), Tinca tinca (Tincinae), and Pseudorasbora parva (Gobioninae) were used as outgroups in phylogenetic analyses.

Total cellular DNA was extracted from both ethanol preserved or frozen tissue by a standard proteinase $\mathrm{K}$ and phenol/chloroform extraction method [136] and ethanol purification [137]. Both mitochondrial (cytochrome $b$ and COxI) and nuclear (RAG1 and S7) genes were amplified via polymerase chain reaction (PCR) from each individual DNA sample. Primers, amplification protocols and PCR products lengths for these loci are represented in Additional file 2. In all cases, PCR mixtures were prepared under similar conditions in a final volume of $25 \mu \mathrm{l}$ containing 1-2 $\mu \mathrm{l}$ DNA, $0.5 \mu \mathrm{M}$ each primer, $0.2 \mathrm{mM}$ each dNTP, $1.5 \mathrm{mM} \mathrm{MgCl} 2$, and 1 unit of Taq DNA polymerase (Invitrogen). After checking PCR products on 1.5\% agarose gels, the four genetic fragments were purified with the kit ExoSAP-IT ${ }^{\mathrm{mm}}(\mathrm{USB})$ and directly sequenced. For RAG1 some internal primers were designed to sequencing (See Additional file 2). All samples were sequenced on an Applied Biosystems 3700 DNA sequencer following the manufacturer's instructions. All new are available online [Genbank:

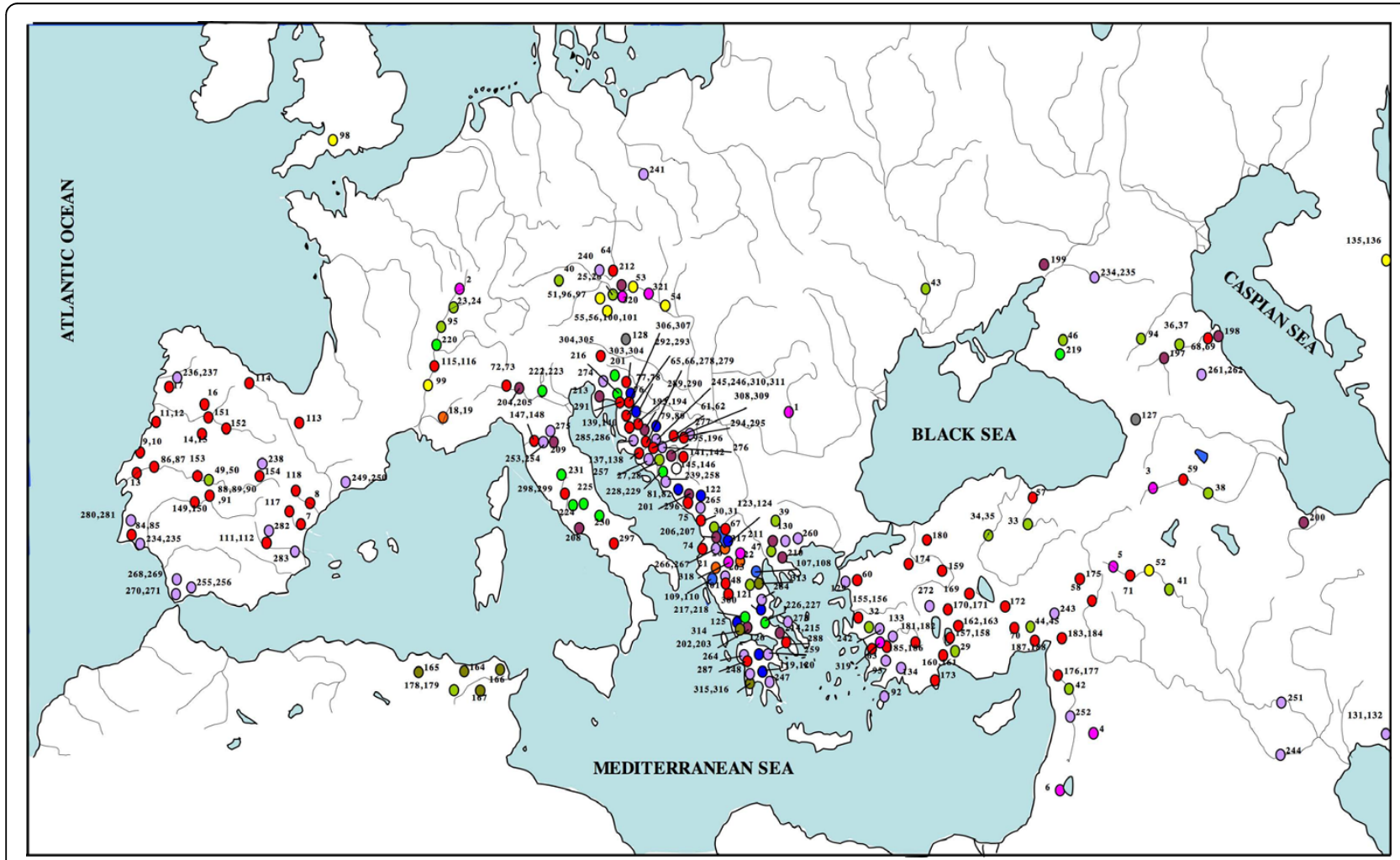

Figure 10 Map of localities samples of the leuciscine representatives included in the phylogenetic framework. Numbers correspond to those indicated in the Additional file 1. 
HM560056-HM560237 for cyt $b$; HM560238-HM560383 and HM989722-HM989724 for COxI; HM560384HM560471, HM560573-HM560586 and HM998711HM998712 for RAG1; HM560472-HM560572 and HM998713-HM998714 for S7].

\section{Sequences alignment and Phylogenetic Analyses}

Homologous regions were aligned manually against previously published cytochrome $b$ sequences of leuciscins $[4,5]$. Chromatograms and alignments were visually checked and verified and there were no gaps in the resulting cyt $b$, COxI and RAG1. In these three coding genes sequences alignment was based on the inferred amino acid sequence. Alignments sequences of all performed analyses are proporcioned in Additional file 3. All codon posititions were included in the analysis. The first intron of S7 gene were aligned with Clustal X [138], using default parameters, to optimize sequence alignment including gaps and aligned sequences were later checked by eye. Despite of indels are often considered as a class of phylogenetic characters to be incorporate in the phylogenetic analysis $[139,140]$, gaps of S7 gene was discarded in phylogenetic reconstructions due to their ambiguity in the alignment.

For all data sets, the transition (ti)/transversion (tv) rate was estimated using a maximun-likelihood approach (Table 1). Furthermore, for each gene, the saturation of transition and transversion changes was checked by plotting the absolute number of changes of each codon position against patristic distances (p). There was no evidence of saturation for any data set of sequences, even in the third position of coding genes.

Analyses were performed independently on each gene (cyt $b$, COxI, RAG1 and S7), in nuclear data sets and on the total number of base pairs sequenced (4339 bp) ("Total evidence", [141]). Nucleotide composition was examined and the $\chi^{2}$ homogeneity test of base frequencies was carried out in Paup "4.0b10 [142] for all genes. The Akaike Information Criterion implemented in ModelTest v. 3.7 [67] was used to determine the evolutionary model that best fits the data set for each data set. The model selected was used for subsequent analyses. Bayesian inference (BI) was performed with MrBayes 3.1.2 [143]. In the combined data set each gene partition was allowed to follow its own model of evolution. In all cases, BI was obtained by simulating two simultaneous Markov chain analyses (MCMC) for 3.000 .000 generations each, to estimate the posterior probabilities distribution. Topologies were sampled every 100 generations and a majority-rule consensus tree was estimated after eliminated the first $10^{5}$ generations in each analysis. Maximum Likelihood (ML) analysis was performed with PhyML package [144]. To estimate the robustness of the likelihood analyses a nonparametric bootstrap test was
Table 5 Fossil calibration points

\begin{tabular}{lc}
\hline Clade & Mya \\
\hline Squalius cephalus clade & 6.5 \\
Squalius lineage & 13 \\
Achondrostoma/Pseudochondrostoma clades & 5.3 \\
Scardinius clade & 10 \\
Scardinius erythrophthalmus clade & 5.3 \\
Leuciscus leuciscus/leuciscus idus clade & 5.3 \\
Miminun Recent Common Ancestor of all Iberian taxa & 25 \\
Abramidini clade & 17 \\
Split among Phoxinus and leuciscine groups & 33 \\
\hline
\end{tabular}

conducted with 500 replicates. Maximum Parsimony (MP) [145] analysis was performed with the package PAUP* 4.0b10 [142]. MP analysis was conducted with TBR branch swapping and 10 random stepwise additions using the heuristic search algorithm. Analyses were performed on each independent data set and on the total data matrix after check homogeneity among partitions [146]. Confidences for this analysis were estimated by bootstrapping (500 repetitions) [147].

\section{Molecular clock and divergence times estimates}

As a general clock-like behaviour was rejected, divergence times and their credibility intervals (highest posterior density: HPD) were estimated using a relaxed clock model in BEAST v1.4.7 [148], with branch rates drawn from an uncorrelated lognormal distribution [149] and a Yule speciation prior. Fossil evidence was used to place the constraints of the age of different nodes within the topology. The use of multiple calibration points would provide a more realistic divergence time estimates. The calibration points used to estimate divergence times are represented in Table 5. Tracer v1.4 [148] was used to plot the log-likelihood scores against generation time to evaluate run convergence and the burn-in needed before to reconstruct the $50 \%$ majorityrule consensus tree of the post burn-in trees. To obtain a maximum clade credibility tree, trees were summarized with the software TreeAnnotator 1.4.6 [148].

\section{Additional material}

Additional file 1: Individuals included in the phylogeny and localities samples

Additional file 2: Laboratory performance (PCR conditions and primers).

Additional file 3: Sequences alignments used in phylogenetic performance and molecular clock analyses.

\section{Acknowledgements}

We thank F. Alda, P. Ornelas, C. Pedraza, A. Perdices, O. Dominguez, J. A. Carmona and I. Bogut for their help in fieldwork. L. Alcaraz assisted in the 
laboratory work. N. Bogutskaya for providing samples of Leuciscus. cf. latus. A. Burton reviewed the English text. RS was supported by the project MK00002327201 of the Czech Ministry of Culture. RS received also support from the SYNTHESYS Project (ES-TAF-1187) financed by European Community Research Infrastructure Action under the FP6 "Structuring the European Research Area" Programme". This study was financially sponsored by Spanish Ministry of Education and Culture project CGL2007/61231 and Spanish Agency for International Development Cooperation (AECID) project 07-CAP-1523.

\section{Author details}

'Museo Nacional de Ciencias Naturales-CSIC. Department of Biodiversity and Evolutionary Biology. José Gutiérrez Abascal 2, 28006 Madrid. Spain. ${ }^{2}$ Senckenberg Centre for Human Evolution and Paleoecology (HEP) and Institute for Geoscience, University Tübingen, Sigwartstr. 10, D-72076 Tübingen, Germany. ${ }^{3}$ AZV Agency. Dolsko 14, S1-1262. Slovenia. ${ }^{4}$ LeibnizInstitute of Freshwater Ecology and Inland Fisheries. Müggelseedamm 310, 12587 Berlin. Germany. ${ }^{5}$ National Museum. Václavské náměstí 68, 11579 Prague 1. Czech Republic. ${ }^{6}$ Istanbul University. Faculty of Science. Department of Biology, 34134 Vezneciler, İstanbul. Turkey. ${ }^{7}$ Department of Biodiversity and Ecosystem Management, Environmental Sciences Research Institute. Shahid Beheshti University G. C., Tehran, Iran.

\section{Authors' contributions}

SP conceived the study, collected samples, obtained data and analyses and drafted the manuscript. MB contributed to review and support the biogeographical chapter with paleontological and fossil data. PZ, JF and RS collected samples, reviewed the manuscript and make useful suggestions for it. MO and AA collected valuables samples for the study. ID participated in its design and coordination, helped to draft the manuscript and collected samples. All authors read and approved the final manuscript.

Received: 25 February 2010 Accepted: 31 August 2010

Published: 31 August 2010

\section{References}

1. Banarescu P, Coad BW: Cyprinidae of Eurasia. In Cyprinid fishes, Systematics, Biology and Explotation. Edited by: Winfield IJ, Nelson JE. London: Chapman and Hall; , 1 1991:127-155.

2. Kottelat M, Freyhof J: Handbook of European Freshwater Fishes. Berlin 2007.

3. Nelson JE: Fishes of the world., 42006

4. Zardoya R, Doadrio I: Phylogenetic relationships of Iberian cyprinids: Systematics and biogeographical implications. Proc R Soc Lond B 1998, 265:1365-1372.

5. Zardoya R, Doadrio I: Molecular evidence of the evolutionary and biogeographical patterns of European cyprinids. J Mol Evol 1999, 49:227-237.

6. Durand JD, Tsigenopoulos CS, Ünlü E, Berrebi P: Phylogeny and Biogeography of the family Cyprinidae in the Middle East inferred from cytochrome $b$ DNA-Evolutionary significance of this region. $\mathrm{Mol}$ Phylogenet Evol 2002, 22(1):91-100.

7. Durand JD, Bianco PG, Laroche J, Gilles A: Insight into the origin of endemic Mediterranean ichthyofauna: phylogeography of Chondrostoma genus (Teleostei, Cyprinidae). J Hered 2003, 94(4):315-328.

8. Myers GS: Fresh-water fishes and West Indian zoogeography. Annual Report of the Board of Regents of the Smithsonian Institution 92 (1938, for the year 1937) 1938, 339-364

9. Bermingham E, Martin AP: Comparative mtDNA phylogeography of neotropical freshwater fishes: testing shared history to infer the evolutionary landscape of lower Central America. Mol Ecol 1998, 7(4):499-517.

10. Doadrio I: Delimitation of areas in the Iberian Peninsula on the basis of the freshwater fishes. Bonn Zool Beiträge 1998, 39:113-128.

11. Durand JD, Templeton AR, Guinand B, Imsiridou A, Bouvet Y: Nested clade and phylogeographic analyses of the chub, Leuciscus cephalus (Teleostei, Cyprinidae), in Greece: implications for Balkan Peninsula biogeography. Mol Phylogenet Evol 1999, 13(3):566-580

12. Arai R: A chromosome study on two Cyprinid Fishes Acrossocheilus labiatus and Pseudorasbora pumila pumila, with notes on Eurasian
Cyprinids and their karyotypes. Bull Natn Sci Mus, Tokyo Ser A 1982, 8:131-152.

13. Chen $X L$, Yue $P Q$, Lin $R D$ : Major groups within the family Cyprinidae and their phylogenetic relationship. Acta Zool Sinica 1984, 9:424-440.

14. Howes GJ: The anatomy, phylogeny, and classification of bariliine cyprinid fishes. Bull Brit Mus Nat Hist Zoology 1980, 37:129-198.

15. Cavender TM, Coburn MM: Phylogenetic relationship of North American Cyprinidae. In Systematics, historical ecology and North American freshwater fishes. Edited by: Mayden RL. California: Standford University Press. 1992:293-327.

16. Chen W-J, Mayden RL: Molecular systematics of the Cyprinoidea (Teleostei: Cypriniformes, the world's largest clade of freshwater fishes: Further evidence from six nuclear genes). Mol Phylogenet Evol 2009, 52:544-549.

17. Mayden RL, Chen W-J: The world's smallest vertebrae species of the genus Paedocypris: A new family of freshwater fishes and the sister group of the world's most diverse clade of freshwater fishes (Teleostei: Cypriniformes). Mol Phylogenet Evol 2010

18. Briolay J, Galtier N, Brito RM, Bouvet Y: Molecular Phylogeny of Cyprinidae inferred from cytochrome b DNA sequences. Mol Phylogenet Evol 1998, 9:100-108.

19. Gilles A, Lecointre G, Miquelis A, Loerstcher M, Chappaz R, Brun G: Partial combination applied to phylogeny of European cyprinids using the mitochondrial control region. Mol Phylogenet Evol 2001, 19:22-23.

20. Cunha C, Mesquita N, Dowling TE, Gilles A, Coelho MM: Phylogenetic relationships of Eurasian and American cyprinids using cytochrome $b$ sequences. J Fish Biol 2002, 61:929-944.

21. Liu H, Tzeng CS, Teng HY: Sequence variation in the mtDNA control region and their implications for the phylogeny of Cypriniformes. Can Zool 2002, 81:1938-1946.

22. Saitoh K, Sado T, Mayden RL, Hanzawa N, Nakamura K, Nishida M, Miya M: Mitogenic evolution and relationships of the Cypriniformes (Actinopterygii, Ostariophysi): the first evidence toward resolution of higher-level relationships of the world's largest freshwater fish clade based on59 whole mitogenome sequences. J Mol Evol 2006, 63(6):826-841.

23. Rüber L, Kottelat M, Tan HH, Ng PKL, Britz R: Evolution of miniaturization and the phylogenetic position of Paedocypris, comprising the world's smallest vertebrate. BMC Evol Biol 2007, 7(38)

24. Bogutskaya NG: Morphological basics in cyprinid fish of Leuciscinae subfamily (Leuciscinae, Cyprinidae). Vop Ikthiol 1990, 30(6):920-933.

25. Howes GJ: Systematic and Biogeography: an overview. In Cyprinid fishes: Systematic, biology and explotaition. Edited by: Winfield IJ, Nelson JE. London: Chapman and Hall; 1991:1-33.

26. Wang X, Li J, He S: Molecular evidence for the monophyly of East Asian groups of Cyprinidae (Teleostei: Cypriniformes) derived from the nuclear recombination activating gene 2 sequences. Mol Phylogenet Evol 2007, 42(1):157-170

27. Bufalino AP, Mayden RL: Phylogenetic relationships of North American phoxinins (Actinopterygii: Cypriniformes: Leuciscidae) as inferred from S7 nuclear DNA sequences. Mol Phylogenet Evol 2010, 55:143-152.

28. Cavender TM: The fossil record of Cyprinidae. In Cyprinid Fishes: Systematic Biology and Exploitation. Edited by: Winfield IJ, Nelson JE. London: Chapman and Hall; 1991:34-54.

29. Gaudant J: The Miocene non-marine fish-fauna of Central Europe: A review. Bull Acad serbe sci arts 2002, 125:65-74.

30. Schulz-Mirbach T, Reichenbacher B: Reconstruction of Oligocene and Neogene freshwater fish faunas- an actualistic study on cypriniforms otoliths. Acta Paleontol Pol 2006, 51(2):283-304.

31. Rainboth WJ: Cyprinid fishes of Southeast Asia. In Cyprinid fishes: Systematics, biology and exploitation. Edited by: Winfield IJ, Nelson JE. London: Chapman and Hall; 1991:156-210

32. Sanjur Ol, Carmona JA, Doadrio I: Evolutionary and biogeographical patterns within Iberian populations of the genus Squalius inferred from molecular data. Mol Phylogenet Evol 2003, 29:20-30.

33. Doadrio I: Freshwater fish fauna of North Africa and its biogeography. Kontinlijk Museum voor Midden Africa Tervuren Belgie Annalen Zoologische Wetenschappen 1994, 275:21-34

34. Banarescu P: Zoogeography and history of the freshwater fish faune of Europe. In The freshwater fishes of Europe. Edited by: Holcik J. Wiesbaden: Aula Verlag; 1989:1:80-107. 
35. Banarescu P: Zoogeography of Fresh Waters. Distribution and dispersal of freshwater animals in North America and Europe. Wiesbaden: Aula Verlag 1992, 2

36. Economidis PS, Banarescu P: The distribution and origin of freshwater fishes in the Balkan Peninsula, especially in Greece. Int Rev Ges Hydrobio 1991, 76:257-283.

37. Doadrio I, Carmona JA: Testing freshwater Lago Mare dispersal theory on the phylogeny relationships of Iberian cyprinids genera Chondrostoma and Squalius (Cypriniformes, Cyprinidae). Graellsia 2003, 59(2-3):457-473.

38. Bianco PG: Potencial role of Mediterranean and Paratethys basin on the early dispersal of the Europe-Mediterranean freshwater fishes. Ichthyol Explor Fres 1990, 1:167-184.

39. Hsü K, Montadert L, Bernuilli D, Cita MB, Erickson A, Garrison BE, Kidd RB, Mèlierés F, Müller C, Wright R: History of the Mediterranean salinity crisis. Nature 1977, 267:399-403.

40. Krijgsman W, Hilgen FJ, Raffi I, Sierro F, Wilson DS: Chronology, causes and progression of the Messinian salinity crisis. Nature 1999, 400:652-655.

41. Penzo E, Gandolfi G, Bargelloni L, Colombo L, Patarnello T: Messinian salinity crisis and the origin of freshwater lifestyle in western Mediterranean Gobies. Mol Biol Evol 1998, 15(11):1472-1480.

42. Ketmaier V, Bianco PG, Cobolli M, Krivokapic M, Caniglia M, Matthaeis dE: Molecular phylogeny of two lineages of Leuciscinae cyprinid (Telestes and Scardinius) from peri-Mediterranean area based on cytochrome b data. Mol Phylogenet Evol 2004, 32:1061-1071.

43. Doadrio I, Carmona JA: Phylogenetic relationships and biogeography of the genus Chondrostoma inferred from mitochondrial DNA sequences. Mol Phylogenet Evol 2004, 33:802-815.

44. Coad BW: Zoogeography of the freshwater fishes of Iran. In Proceedings of the Symposium on the Fauna and Zoogeography of the Middle East. Edited by: Krupp F, Schneider W, Kinzelbach R. Weisbaden: Beihefte zum. TAVO A 28; 1987:.

45. Coad BW: Zoogeography of the fishes of the Tigris-Euphrates basin. Zool Middle East 1996, 13:51-70.

46. Berg LS: Freshwater fishes of USSR and adjacent countries. Jerusalem: IPST Press 1949, 1-3.

47. Tsigenopoulos CS, Berrebi P: Molecular phylogeny of North Mediterranean freshwater barbs (genus Barbus: Cyprinidae) inferred from cytochrome b sequences: biogeographic and systematic implications. Mol Phylogenet Evol 2000, 14:165-179.

48. Durand JD, Ünlü E, Doadrio I, Pipoyan S, Templeton AR: Origin, radiation, dispersion and allopatric hybridisation in the chub, Leuciscus cephalus. Proc R Soc Lond B 2000, 267:1687-1697.

49. Banarescu P: Zoogeography of Fresh Waters. General distribution and dispersal of freshwater animals. Wiesbaden: Aula Verlag 1990, 1.

50. Kotlik P, Berrebi P: Phylogeography of the barbel (Barbus barbus) assessed by mitochondrial DNA variation. Mol Ecol 2001, 10(9):2177-2185.

51. Kotlik P, Bogutskaya NG, Ekmeckçi FG: Circum Black Sea phylogeography of Barbus freshwater fishes: divergence in the Pontic glacial refugium. Mol Ecol 2004, 13(1):87-95.

52. Hewitt G: The genetic legacy of quaternary ice ages. Nature 2000 405:907-913.

53. Hewitt G: Genetic consequences of climatic oscillations in the Quaternary. Philos Trans Roy Soc Lond B 2004, 359(1442):183-195.

54. Tsigenopoulos CS, Durand JD, Ünlü E, Berrebi P: Rapid radiation of the Mediterranean Barbus species (Cyprinidae) after the Messinian salinity crisis of the Mediterranean Sea, inferred from mitochondrial phylogenetic analysis. Zool J Linn Soc 2003, 80(2):207-222.

55. Doadrio I: Phylogenetic relationships and classification of west Paleartic species of the genus Barbus (Osteichthyes, Cyprinidae). Aquat Living Resour 1990, 3:265-282.

56. Meyer A: Evolution of the mitochondrial DNA in fishes. In Biochemestry and Molecular Biology of Fishes. Edited by: Hochachka PW, Mommsen TP. Amsterdam: Elsevier; 1993:2:3-38.

57. Zardoya R, Meyer A: Phylogenetic performance of mitochondrial protein coding genes in resolving relationships among vertebrates. Mol Biol Evol 1996, 13:933-942.

58. Brito RM, Briolay J, Galtier N, Bouvet Y, Coelho MM: Phylogenetic relationships within the genus Leuciscus (Pisces, Cyprinidae) in Portuguese freshwaters, based on mitochondrial cytochrome b sequences. Mol Phylogenet Evol 1997, 8:435-442.
59. Hebert PDN, Cywinska A, Ball SL, de Waard JR: Biological identifications through DNA barcodes. Proc R Soc Lond B 2003, 270:313-321.

60. Ward RD, Zemlak TS, Innes BH, Last PR, Hebert PDN: DNA barcoding Australia's fish species. Philos Trans Roy Soc Lond B 2005, 360:1847-1857.

61. Hänfling B, Brandl R: Phylogenetics of European cyprinids: insights from allozymes. J Fish Biol 2000, 57:265-276.

62. Ketmaier V, Bianco PG, Cobolli M, De Matthaeis E: Genetic differentiation and biogeography in southern European populations of the genus Scardinius (Pisces, Cyprinidae) based on allozyme data. Zool Scr 2003, 32(1):13-22

63. Freyhof J, Lieckfeldt D, Bogutskaya NG, Ludwig A: Phylogenetic position of the Dalmatian genus Phoxinellus and description of Delminichthys, new genus, (Teleostei: Cyprinidae). Mol Phylogenet Evol 2006, 38:416-425.

64. Robalo J, Sousa-Santos C, Levy A, Almada VC: Molecular insights on the taxonomic position of the paternal ancestor of the Squalius alburnoides hybridogenetic complex. Mol Phylogenet Evol 2007, 39(1):276-281.

65. Robalo J, Almada VC, Levy A, Doadrio I: Re-examination and phylogeny of the genus Chondrostoma based on mitochondrial and nuclear data and the definition of 5 new genera. Mol Phylogenet Evol 2007, 42:362-372.

66. He S, Mayden RL, Wang X, Wang W, Tang KL, Chen W-J, Chen Y: Molecular phylogenetics of the family Cyprinidae (Actinpoterygii: Cypriniformes) as evidenced by sequence variation in the first intron of S7 ribosomal protein-coding gene: further evidence from a nuclear gene of the systematic chaos in the family. Mol Phylogenet Evol 2008, 46(3):818-829.

67. Posada D, Crandall KA: Modeltest: testing the model of DNA substitution. Bioinformatics 1998, 14(9):817-818.

68. Rannala B, Yang Z: Probability distribution of molecular evolutionary trees: a new method of phylogenetic inference. J Mol Evol 1986, 43:304-311.

69. Yang Z, Rannala B: Bayesian phylogenetic inference using DNA sequences: a Markov Chain Monte Carlo method. Mol Biol Evol 1997, 14:717-724.

70. Simmons MP, Miya M: Efficiently resolving the basal clades of a phylogenetic tree using Bayesian and Parsimony approaches: a case study using mitogenomic data from 100 higher teleost fishes. Mol Phylogenet Evol 2004, 31(1):351-362.

71. Huelsenbeck JP, M HD: Success of phylogenetic methods in the four taxon case. Syst Biol 1993, 42:247-264.

72. Kraiem MM: Les poissons d'eau douce de tunisie: inventaire commenté et repartition geographique. Bull Inst Nain Scient Tech Oceanogr Pêche Salammbô 1983, 10:107-124.

73. Collares-Pereira MJ: Les phoxinelles circum-mediterranées (avec la description d'Anaecypris N. Gen.) (Poissons, Cyprinidae). Cybium 1983, 7(3):1-7.

74. Lelek A: The freshwater fishes of Europe. Threatened fishes of Europe. European Committee for the conservation of Nature and Natural Resources. Council of Europe 1987.

75. Ladiges W, Vogt D: Die Süsswasserfische Europas. Hamburg: Paul Parey 1979.

76. Bogustkaya NG: A revision of species of the genus Pseudophoxinus (Leuciscinae, Cyprinidae) from Asia Minor. Mitt Hamb Zool Mus Inst 1992, 89:261-290.

77. Bogustkaya NG, Küçük F, Atalay MA: A description of three new species of the genus Pseudophoxinus from Turkey (Teleostei: Cyprinidae: Leuciscinae). Zoosyst Ross 2007, 15(2):335-341.

78. Hrbek T, Stölting KN, Bardakci F, Küçük F, Wildekamp RH, Meyer A: Plate tectonics and biogeographical patterns of the Pseudophoxinus (Pisces: Cypriniformes) species complex of central Anatolia, Turkey. Mol Phylogenet Evol 2004, 32(1):297-308.

79. Bogutskaya NG, Zupančič P: Phoxinellus pseudalepidotus, a new species from the Neretva basin (Teleostei: Cyprinidae) with an overview of the morphology of Phoxinellus species of Croatia and Bosnia and Herzegovina. Ichthyol Explor Fres 2003, 14:369-383.

80. Imsiridou A, Apostodilis AP, Durand JD, Briolay J, Bouvet Y, C T: Genetic differentiation and phylogenetic relationships among Greek chub Leuciscus cephalus L. (Pisces, Cyprinidae) populations as revealed by RFLP analysis of amplified mitochondrial DNA segments. Biochem Syst Ecol 1998, 26:415-429.

81. Bogustkaya NG: Petroleuciscus, a new genus for the Leuciscus borysthenicus species group (Teleostei: Cyprinidae). Zoosyst Ross 2002, 11(1):235-237. 
82. Bogustkaya NG, Poznyak VG: Redescription of Leuciscus aphipsi Aleksandrov (Leuciscinae, Cyprinidae). Vop Ikthiol 1994, 34(3):308-315.

83. Bogustkaya NG: Ontogeny an Evolutionary development of sensory canal system in cyprinid fishes. J Morphol 1994, 220(3):327.

84. Bogustkaya NG, Naseka AM: Catalogue of agnathans and fishes of fresh and brackish waters of Russia with comments on nomenclature and taxonomy. Moscow: Russian Academy of Sciences 2004.

85. Coad BW: Pseudophoxinus persidis, a new cyprinid fish from Fars, southern Iran. Can J Zool 1981, 59(11):2058-2063.

86. Bogutskaya NG: Contribution to the knowledge of leuciscine fishes of Asia Minor. Part 1. Morphology and taxonomic relationships of Leuciscus borysthenicus (Kessler), Leuciscus smyrnaeus Boulenger and Ladigesocypris ghigii (Gianferrari) (Cyprinidae, Pisces). Pulicación Especial del Instituto Español de Oceanografía 1996, 21:25-44

87. Bianco PG: Leuciscus cephalus (Linnaeus), with record of fingerling adult males, Leuciscus pleurobipunctatus (Stephanidis) and their hybrids from western Greece. J Fish Biol 1988, 32:1-16.

88. Bianco PG: L'ittiofauna continentale dell'Appennino umbromarchigiano, barriera semi permeabile allo scambio di componenti primarie tra fli opposite versanti dell'Italia centrale. Biogeographia 1994, 17:427-485.

89. Bianco PG, Ketmaier $V$, Bussato T: Approccio multidisciplinare all'analisi tassonomica del genere Scardinius (Cyprinidae) en Europa. Quaderni ETP 2001, 30:115-120.

90. Machordom A, Doadrio I: Evidence of a Cenozoic Betic-Kabilian connection based on freshwater fish phylogeography (Luciobarbus, Cyprinidae). Mol Phylogenet Evol 2001, 18:252-263.

91. Dowling TE, Tibbets CA, Minckley WL, Smith RG: Evolutionary relationships of the plagoterins (Teleostei: Cyprinidae) from cytochrome b sequences. Copeia 2002, 2002(3):655-678

92. Yang Z, Yoder AD: Comparison of likelihood and Bayseian methods for estimating divergence times using multiple gene loci and calibration points, with application to a radiation of cute-looking mouse lemur species. Syst Biol 2003, 52:705-716.

93. Levy A, Doadrio I, Almada VC: Historical biogeography of European leuciscins (Cyprinidae): evaluating the Lago Mare dispersal hypothesis. J Biogeogr 2009, 36:55-65.

94. Böhme M: Die Cypriniden (Teleostei, Cypriniformes) des oberoligozänen Maares von Enspel nebst Bemerkungen zur Phylogenie und Biogeographie der Phoxininae. Palaeontol Z 2000, 74(1/2):99-112.

95. Böhme M: Revision of the cyprinids from the Early Oligocene of the České Středohoří Mountains and the phylogenetic relationships of Protothymallus LAUBE 1901 (Teleostei, Cyprinidae). Acta Mus Nat Prag 2007, 63(2-4):177-196.

96. Rögl F: Mediterranean and Paratethys. Facts and hypotheses of an Oligocene to Miocene paleogeography (short overview). Geol Carpath 1999, 50:339-349.

97. Krijgsman W, Duermeijer CE, Langereis CG, de Bruijn H, Saraç G, Andriessen PAM: Magnetic polarity stratigraphy of late Oligocene to middle Miocene mammal-bearing continental deposits in Central Anatolia (Turkey). News/ Stratigr 1996, 34(1):13-30.

98. Theocharopoulus KD: Late Oligocene-Middle Miocene Democricetodon, Spanocricetodon and Karydomys n. gen. from the Eastern Mediterranean area. National and Kapodistrian University of Athens. Edition of the Department of Geology 2000, 8.

99. Ratschbacher L, Merle O, Davy P, Cobbold P: Lateral extrusion in the Eastern Alps, part I: boundary conditions and experiments scaled for gravity. Tectonics 1991, 10:245-256.

100. Frisch W, Kuhlemann J, Dunkl I, Brügel A: Palinspastic reconstruction and topographic evolution of the Eastern Alps during the late Tertiary extrusion. Tectonophysics 1998, 297:1-15.

101. Paramonova NP, Shcherba IG, Khondkarian SO: Map 7: late Middle Miocene (Late Serravallian, Sarmatian s.s., Middle Sarmartian s.I.). In Lithological-Palaeogeographic maps of Paratethys. Edited by: Popov SV, Rögl F, Rozanov AY, Steininger FF, Shcherba IG, Kovac M. Cour. Forsch. Inst. Senckengerg; 2004:250:27-29.

102. Kuhlemann J: Paleogeographic and paleotopographic of the Swiss and Eastern Alps since the Oligocene. Global Planet Change 2007, 58:224-236.

103. Marton E: Palaeomagnetism and palaeogeography. In The Geology of Central Europe Volumen 2: Mesozoic and Cenozoic. Edited by: McCann T. London: Geological Society; 2008:1033-1035.
104. Hinsbergen DJJV, Dupont-Nivet G, Nakov R, Oud K, Panaiotu C: No significant post-Eocene rotation of the Moesian Platform and Rhodope (Bulgaria): Implications fort he kinematic evolution of the Carpatian and Aegean arcs. Earth Planet Sc Lett 2008, 273:345-358.

105. Bartol M, Pavšič J, Dobnikar M, Bernasconi SN: Unusual Braarudosphaera bigelowii and Micrantholithus vesper enrichment in the Early Miocene sediments from the Slovenian Corridor, a seaway linking the Central Paratethys and the Mediterranean. Palaeogeogr Palaeod 2008, 267(12):77-88.

106. Böhme M: Eine Untermiozäne Fischfauna (Teleostei, Cyprinidae) vom Dietrichsberg bei Vacha/Rhön. Freiberger Forschungshefte, Reihe C 1993 450:116-150.

107. Böhme M: Small Cyprinids from the Tertiary of Europe - the genus Palaeoleuciscus (Leuciscinae). 9 International Congress of European Ichthyologists: 1997; Trieste 1997, 15.

108. Obrhelova N: Cyprinoidei aus dem Hangenden des Miozänen Braunkohleflözes Nordböhmens. Palaeontographica 1967, 126(A):141-179.

109. Obrhelova N: Fische des nordböhmischen Braunkohlebeckens. Acta Mus Nat Prag 1990, 46(1-2):1-35

110. Puigdefńbregas C, Muñoz JA, Vegés J: Thrusting and foreland basin evolution in the Southern Pyrenees. In Thrust Tectonics. Edited by: McClay KR. London: Chapman and Hall; 1992:247-254.

111. Muñoz JA, Martiínez A, Vegés J: Thrust sequences in the eastern Spanish Pyrenees. J Struct Geol 1986, 8:399-405.

112. López-Martínez N: Tendencias en paleobiogeografía. El futuro de la biogeografía del pasado. In Paleontología. Edited by: Aguirre E. Madrid: CSIC; 1989:271-296.

113. Steininger FF, Rögl F: Paleogeography and palinspastic reconstruction of the Neogene of the Mediterranean and Paratethys. In The geological evolution of the Eastern Mediterranean. Edited by: Dixon JE, Robertson AH. Oxford: Blackwell; 1984:17:659-668.

114. Susnik S, Snoj A, Dove P: Evolutionary distinctness of grayling \{Thymallus thymallus) inhabiting the Adriatic river system, as based on mtDNA variation. Biol J Linn Soc 2001, 74(3):375-385.

115. Stefani F, Galli P, Crosa G, Zaccara S, Calamari D: Alpine and Apennine barriers determining the differentiation of the rudd (Scardinius erythrophthalmus L.) in the Italian peninsula. Ecol Freshw Fish 2004, 13:168-175.

116. Harzhauser M, Mandic O: Neogene lake systems of Central and SouthEastern Europe: Faunal diversity, gradients and interrelations. Palaeogeogr Palaeod 2008, 260:417-434.

117. Pavelić D, Belak M: Dinarids in north Croatia and Bosnia. In The Geology of Central Europe Volume 2 Mesozoic and Cenozoic. Edited by: McCann T. London: Geological Society; 2008:1102-1116.

118. Harzhauser M, Kroh A, Mandic O, Piller WE, Göhlich U, M R, Berning B: Biogeographic responses to geodynamics: A key study all around the Oligo-Miocene Tethyan Seaway. Zool Anz 2007, 246:241-256.

119. Böhme M: Eine Weichschildkröte (Trionychidae) aus dem Untermiozän vom Dietrichsberg bei Vacha (Rhön). Mauritania (Altenburg) 1995, 15(3):357-366

120. Otero O: The oldest-known cyprinid fish of the Afro-Arabic Plate, and its paleobiogeographical implications. J Vertebr Paleontol 2001, 21(2):386-388.

121. Çağatay MN, Görür N, Flecker R, Sakinç M, Tünoğlu C, Ellam R, Krijgsman W, Vincent S, Dikbaş A: Paratethyan-Mediterranean connectivity in the Sea of Marmara region (NW-Turkey) during the Messinian. Sediment Geol 2006, 188-189:171-187.

122. Sprovieri M, Sacchi M, Rohling EJ: Climatically influenced interaction between the Mediterranean and the Paratethys during the Tortonian. Paleoceanography 2003, 18(2):1034.

123. Rögl F: Mid-Miocene Circum-Mediterranean palaeogeography. Ber Inst Geol Palaeontol Karl-Franzens Univ Graz Oesterr 2001, 4:49-59.

124. Blondel J, Aronson J: Biology and Wildlife of the Mediterranean Region. Oxford University Press 1999.

125. Butler RWH, McClelland E, Jones RE: Calibrating the duration and timing of the Messinian salinity crisis in the Mediterranean: linked tectonoclimatic signals in thrust-top basins of Sicily. $J$ Geol Soc London 1999, 156(4):827-835

126. Haywood AM, Sellwood BW, Valdés PJ: Regional warming: Pliocene (3 Ma) paleoclimate of Europe and the Mediterranean. Geology 2000, 28(12):1063-1066. 
127. Calvo JP, Daams R, Morales J, López-Martínez N, Agustí J, Anadón P, Armenteros I, Cabrera L, Civis J, Corrochano A, et al: Up to date Spanish continental synthesis and paleoclimatic interpretation. Rev Soc Geol España 1993, 6(29-40):29.

128. Waelbrock C, Labeyrie L, Michel E, Duplessy JC, McManus JF, Lambeck K Balbon $E$, Labracherie M: Sea-level and deep water temperature changes derived from benthic foraminifera isotopic records. Quaternary Science Rev 2002, 21:295-305.

129. Perdices A, Bohlen J, Doadrio I: The molecular diversity of adriatic spined loaches (Teleostei, Cobiitidae). Mol Phylogenet Evol 2008, 46(1):382-390.

130. Šlechtová V, Bohlen J, Freyhof J, Persat H, Delmastro GB: The Alps as barrier to dispersal in cold-adapted freshwater fishes? Phylogeographic history and taxonomic status of the bullhead in the Adriatic freshwater drainage. Mol Phylogenet Evol 2004, 33(1):225-239.

131. Durand JD, Persat H, Bouvet Y: Phylogeography and postglacial dispersion of the chub (Leuciscus cephalus) in Europe. Mol Ecol 1999. 8(6):989-997

132. Culling M, Janko K, Boron A, Vasil'ev V, Coté I, Hewitt G: European colonization by the spined loach (Cobitis taenia) from Ponto-Caspian refugia based on mitochondrial DNA variation. Mol Ecol 2006 15(1):173-190

133. Perdices A, Doadrio I, Economidis PS, Bohlen J, P B: Pleistocene effects on the European freshwater fish fauna: double origin of the cobitid genus Sabanejewia in the Danube basin (Osteichthyes: Cobitidae). Mol Phylogenet Evol 2003, 26(2):289-299.

134. Costedoat C, Pech N, Salducci M-D, Chappaz R, Gilles A: Evolution of mosaichybrid zone between invasive and endemic. Biol J Linn Soc 2004, 85:135-155.

135. Gollman G, Bouvet Y, Karakousis Y, Triantaphyllidis C: Genetic variability in Chondrostoma from Austrian, French, and Greek rivers (Teleostei, Cyprinidae). J Zool Syst Evol Res 1997, 35:165-169.

136. Sambrook J, Fritsch E, Maniatis T: A laboratory manual. New York: Cold Spring Harbor Laboratory 1989

137. Towner P: Purification of DNA. In Essential molecular biology A practical approach. Edited by: Brown T. Oxford: Oxford University Press; 1991:47-68.

138. Thompson J, Gibson T, Plewniak F, Jeanmougin F, Higgins D: The CLUSTAL $\times$ windows interfase: flexible strategies for multiple sequence aligment aided by quality analysis tools. Nucl Acids Res 1997, 25:4876-4882.

139. Wheeler W: Optimization alignment: the end of multiple sequence alignment in phylogenetics? Cladistics 1996, 12:1-9.

140. Simmons MP, Ochoterena H: Gaps as characters in sequence-based phylogenetic analyses. Syst Biol 2000, 49:369-381.

141. Kluge A: A concern for evidence and a phylogenetic hypothesis of relationships among Epicrates (Boidae, Serpentes). Syst Zool 1989 38:7-25.

142. Swofford D: PAUP*, Phylogenetic Analysis Using Parsimony (*and other methods) v4.0b10. Sunderland: Sinauer Associates 2002.

143. Ronquist F, Huelsenbeck JP: MRBAYES 3: Bayesian phylogenetic inference under mixed models. Bioinformatics 2003, 19:1572-1574.

144. Guindon S, Gascuel O: A simple, fast and accurate algorithm to estimate large phylogenies by maximum likelihood. Syst Biol 2003, 52(5):696-704.

145. Fitch W: Towards defining the course of evolution: Minimum change for a specific tree topology. Syst Zool 1971, 20:406-416.

146. Farris J, Källersjö M, Kluge A, Bult C: Testing significance incongruence. Cladistics 1994, 10:315-319.

147. Felsenstein J: Confidence-limits on phylogenies: An approach using the bootstrap. Evolution 1985, 39:783-791.

148. Drummond A, Rambaut A: BEAST: Bayesian evolutionary analysis by sampling trees. BMC Evol Biol 2007, 7:214

149. Drummond A, Ho S, Phillips M, Rambaut A: Relaxed phylogenetics and dating with confidence. PLOS Biol 2006, 4:88.

150. Böhme M, Ilg A: Fossil Fishes, Amphibians, Reptiles - fosFARbase. 2003 [http://www.wahre-staerke.com]

151. Böhme M: Freshwater fishes from the Pannonian of the Vienna Basin with special reference to the locality Sandberg near Götzendorf, Lower Austria. Cour Forsch Sekenbg 2002, 237:151-173.

152. Robins CR, Bailey CE, Bond CE, Brooker JR, Lachner EA, Lea RN, Scott WB: Common and scientific names of fishes from the United States and Canada. 1991, 20.
153. Özuluğ M, Freyhof J: Alburnus demiri, a new species of bleak from Western Anatolia, Turkey (Teleostei: Cyprinidae). Ichthyol Explor Fres 2007, 18(4):307-312

154. Bogutskaya NG: Contribution to the knowledge of leuciscine fishes of Asia Minor. Part 2. An annotated check-list of leuciscine fishes (Leuciscinae, Cyprinidae) of Turkey with descriptions of a new species and two subespecies. Mitt Hamb Zool Mus Inst 1997, 94:161-186.

155. Bogutskaya NG, Kucuk F, Unlu E: Alburnus baliki, a new species of cyprinid fish from the Manavgat River system, Turkey. Ichthyol Explor Fres 2000 11(1):55-64.

156. Eschmeyer WN: Catalog of Fishes. San Francisco: California Academy of Sciencies 2005, 1-3.

157. Lévêque C, Daget J: Cyprinidae. In Check-list of the freshwater fishes of Africa (CLOFFA). Edited by: Daget J, Gosse J-P. Thys van den Audenaerde DFE. Paris and MRAC: ORSTOM; 1984:1:217-342.

158. Doadrio I, Elvira B: A new species of the genus Achondrostoma Robalo, Almada, Levy and Doadrio, 2007 (Actynopterigii, Cyprinidae) from western Spain. Graellsia 2009, 63(2):295-304.

159. Turan D, Yilmaz BT, Kaya C: Squalius kottelati, a new cyprinid species (Teleostei, Cyprinidae) from Orontes River Turkey. Zootaxa 2009, 2270:53-62.

160. Elvira B: Taxonomy of the genus Chondrostoma (Osteichthyes, (yprinidae): an updated review. Folia Zool 1997, 46(1):1-14.

161. Balik S: Freshwater fish in Anatolia, Turkey. Biol Cons 1995, 72:213-223.

162. Gante HF, Santos CD, Alves MJ: A new species of Chondrostoma Aggasiz, 1832 (Cypriniformes, Cyprinidae) with sexual dimorphism from the lower Rio Tejo Basin, Portugal. Zootaxa 2007, 1616:23-35.

163. Freyhof J, Özulug M: Pseudophoxinus evliyae, a new species of spring minnow from Western Anatolia with remarks on the distribution of $P$. ninae and the systematic position of $P$. fahira (Teleostei: Cyprinidae). Ichthyol Explor Fres 2009, 20(4):309-318.

164. Goren M: The Freshwater Fishes of Israel, Israel J Zool 1974, 23:67-118.

165. Bailie J, Groombridge B: IUCN red list of the threatened animals. Gland, Switzerland: IUCN 1996

166. Krupp F, Schneider W: The fishes of the Jordan River drainage basin and Azraq Oasis. Fauna of Arabia Saudi 1989, 10:347-416.

167. Coad BW: Systematic biodiversity in the freshwater fishes of Iran. Ital J Zool 1998, 65:101-108

168. Luo Y: Leuciscinae. In Fauna Sinica Osteichthyes Cypriniformes II. Edited by: Chen Y-Y. Beijing: Science Press; 1998:531

doi:10.1186/1471-2148-10-265

Cite this article as: Perea et al:: Phylogenetic relationships and biogeographical patterns in Circum-Mediterranean subfamily Leuciscinae (Teleostei, Cyprinidae) inferred from both mitochondrial and nuclear data. BMC Evolutionary Biology 2010 10:265.

\section{Submit your next manuscript to BioMed Central and take full advantage of:}

- Convenient online submission

- Thorough peer review

- No space constraints or color figure charges

- Immediate publication on acceptance

- Inclusion in PubMed, CAS, Scopus and Google Scholar

- Research which is freely available for redistribution

Submit your manuscript at www.biomedcentral.com/submit
Biomed Central 